\title{
Tank Farm Surveillance and Waste Status Summary Report for June 1990
}

B. M. Hanlon

Date Published

September 1990

Prepared for the U.S. Department of Energy Office of Environmental Restoration and Waste Management

\footnotetext{
(2) Westinghouse P.O. Box 1970

Hantord Company Richland, Washington 99352

Hanford Operations and Engineering Contractor for the

U.S. Department of Energy under Contract DE-AC06-87RL10930
} 
WHC-EP- $0182-27$

\title{
TANK FARM SURVEILLANCE AND WASTE STATUS
}

SUMMARY REPORT FOR JUNE 1990

\author{
B. Hanton
}

\section{ABSTRACT}

This report is Westinghouse Hanford Company's official inventory for radioactive waste stored in the 200 . Areas underground tanks at the Hanford site. Data that depict the status of stored radioactive waste and tank vessel integrity are contaired within the report. The intent of the report is to provide data on each of the existing 177 large underground waste storage tanks and 56 smaller catch tanks, and to provide supplemental information regarding tank surveillance anomalies and ongoing investigations. 
WHC-EP-0182-27

\section{CONTENTS}

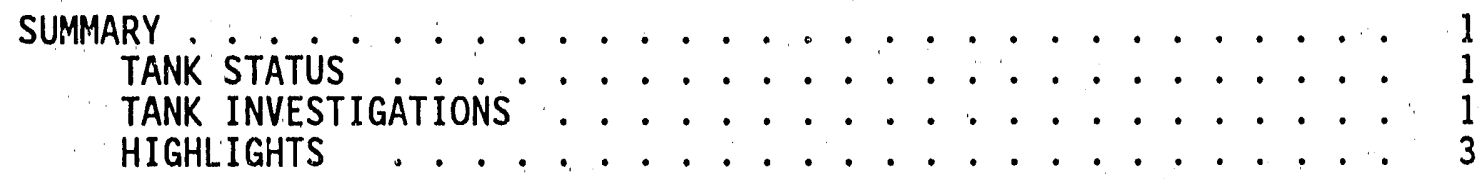

APPENDIXES:

A TANK AND EQUIPMENT CODE AND STATUS DEFINITIONS ..... A-1

B MONTHLY SUMMARY . . . . . . . . . . . . . . . B-1

1 Monthly Summary ................. B-3

2 Tank Use Summary ... . . . . . . . . . . B-5

3 Inventory Summary By Tank Farm . . . . . . . . B-6

4 Inventory And Status By Tank . . . . . . . . . . B-7

C PERFORMANCE SUMMARY ................ C-1

D LIQUID STATUS AND PUMPABLE LIQUID REMAINING IN TANKS . . . D-1

E SALTWELL PUMPING RECORD ................ E-1

F CATCH TANKS .................... F-1

G TANK LEAK DATA . . . . . . . . . . . . . . . . . . G-1 
WHC-EP-0182-27

\section{LIST OF FIGURES}

1 Tank 101-SY, Surface Level Readings . . . . . . . 6

\section{LIST OF TABLES}

1 Temperature Data ................ 5 
WHC -EP-0182-27

TANK FARM SURVEILLANCE AND WASTE STATUS SUMMARY

REPORT FOR JUNE 1990

SUMMARY

Note: Changes from the previous month are in bold print.

\section{TANK STATUS}

\begin{tabular}{|l|c|c|}
\hline \multicolumn{1}{|c|}{ Category } & Quantity & Date of Last Change \\
\hline In-service tanks & 28 double-shell & October 1986 \\
\hline Out-of-service tanks & 149 single-shell & July 1988 \\
\hline Assumed-leaker tanks & 66 single-shell & September 1988 \\
\hline Interim-stabilized tanks $^{b}$ & 101 single-shell & September 1989 \\
\hline Interim-isolated tanks & 91 single-shell & October 1989 \\
\hline
\end{tabular}

all 149 single-shell tanks were removed from service (i.e., no longer authorized to receive waste) as of November 21, 1980.

bof the 101 tanks classified as interim stabilized, 56 have been

listed as Questionable Integrity or Confirmed Leakers in past documents.

\section{TANK INVESTIGATIONS}

Tank 241-SX-104. This tank is being pumped as a result of unexplained liquid level decreases. The tank was declared an "assumed leaker" on July 28, 1988. Approximately 113,231 gal (net) of liquid have been pumped since June 27,1988 . Last pumping occurred June 13, 1989. Jet pumping was scheduled to resume in May 1990, but was postponed until the Safety Analysis addressing the hydrogen issue has been completed.

Tank 241-SY-101. The surface level within this tank continues to fluctuate (Figure 1). The surface level increase/decrease phenomena has been observed since 1981 and is attributed to the buildup and release of gas beneath the crusted surface. An investigation into solutions to the slurry growth problem is ongoing. Multiple Event Fact Sheets, a Critique Report, 0ccurrence Reports \#77-64, 77-92, 77-175, 77-207, 78-16, 79-11, Discrepancy Reports, and an Unusual 0ccurrence Report have been issued. The surface level showed a steady increase from 411.10 to 412.80 in. ( +1.70 in.) during June 1990. The status of this tank will continue to be reported each month. 
Tank 241-5X-109. The radiation peak level exceeded the increase criteria in a peripheral drywe11, 41-00-08, near tank 109-SX, on May 11, 1990. Although 109-SX is categorized ar "assumed leaker," further investigation was requested to determine, if possible, whether the plume migration is from the old leak or from a newer leak. The evaluation was completed by the Geoscience Group on June 29, 1990. It was concluded that the radiation peak level increase is the result of the spread of liquids from an old leak from 109-SX and is not indicative of a newer leak.

Tank 241-TX-107. This tank is categorized an "assumed leaker," and has been interim stabilized and isolated. Four drywells associated with this tank, 51-07-07,51-07-18,51-03-01 and 51-04-05, are continuing to show a trend of increasing radiation levels. The leak detection criteria for drywell radiation levels (200 cps) has not been exceeded. Monitoring of these wells has been increased from an annual to a monthly frequency.

Catch Tank 241-S-302-A. Surface level measurement decreases have been observed after noted increases attributed to rain. An in-tank video of the tank's contents was completed on May 31, 1990. On June 5, 1990, Single-Shell Tank Process Engineering completed an evaluation of the video and concluded that the surface level measurement device (automatic FIC) is contacting a clear liquid surface, with no obstruction that would cause measurement anomalies. The surface level decreases in this tank cannot be accounted for, and are therefore assumed to be indicative of a leak. Event Fact Sheet TF-EFS-90-042 was issued June 8, 1990. Pumping of the tank commenced June 14, 1990, and Unusual Occurrence Report WHC-U0-90-23-TF-05 was issued June 21, 1990. As of June 30, $1990,1,835$ gal have been pumped from this catch tank.

The following tanks are on report for potential in-leakage from known/unknown sources, but are not currently under investigation:

\section{Last indication of an intrusion}

Tank 241-B-104

Tank 241-S-106

Tank $241-T X-112$

Tank $241-T X-115$

Tank 241-TY-102
$07 / 03 / 89$

$05 / 14 / 90$

$03 / 15 / 90$

$10 / 12 / 89$

$07 / 03 / 89$ 
Highlights

Changes to the report:

1) Appendix A. Tank and Equipment Code/Status Definitions

a). Terms used in this appendix have been revised to standardize the terms between two external documents. This applies to the Double-She11 Tanks only at this time. Single-Shell Tanks will be revised after re-evaluation. Until SSTs are reevaluated, there will be some duplication of Waste Type categories.

Waste Type Categories currently used in this report:

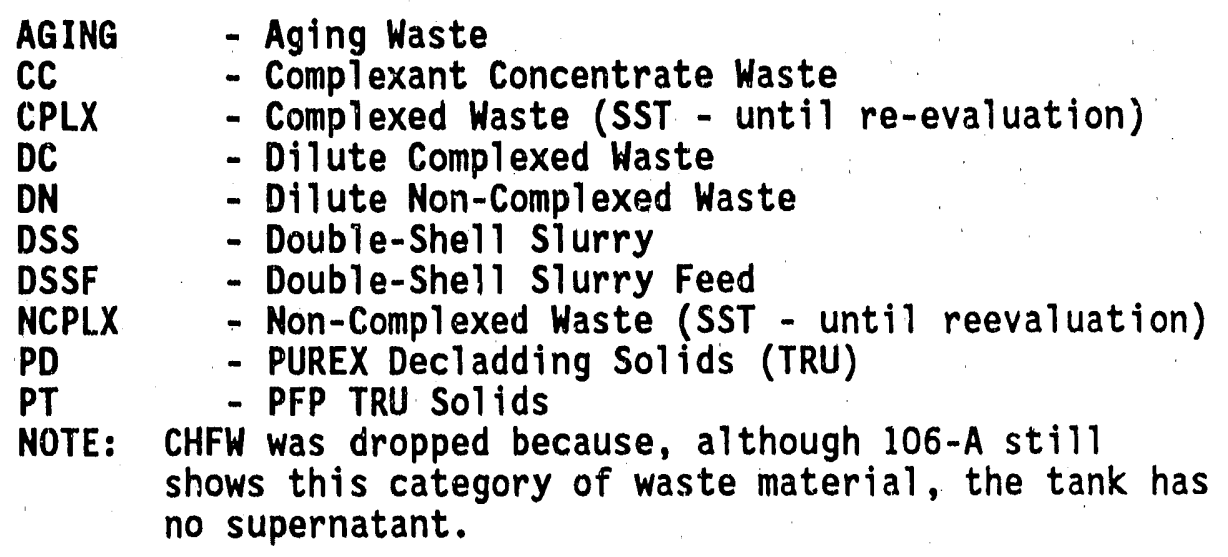

NOTE: CHFW was dropped because, although 106-A still shows this category of waste material, the tank has no supernatant.

Tank Use Designations currently used in this report:

$\begin{array}{ll}\text { CWHT } & \text { - Concentrated Waste Holding Tank } \\ \text { DRCVR } & \text { - Dilute Receiver Tank } \\ \text { EVFD } & \text { - Evaporate Feed Tank } \\ \text { GRTFD } & \text { - Grout Feed Tank } \\ \text { SRCVR } & \text { - Slurry Receiver Tank }\end{array}$

The following changes in the DST Waste Material and Tank Use categories were made. The definitions of these new terms are in Appendix A.1 and A.3.

\begin{tabular}{lllll} 
Tank \# & $\begin{array}{l}\text { Waste Mat'1 Type } \\
\text { (01d) }\end{array}$ & $\begin{array}{l}\text { Use Designation } \\
\text { (NeW) }\end{array}$ & (01d & (New) \\
\hline 101-AN & WRCVR & DRCVR & NCPLX & DN \\
$102-A N$ & SRCVR & CWHT & CC & CC \\
103-AN & SRCVR & CWHT & DSS & DSS
\end{tabular}




\begin{tabular}{|c|c|c|c|c|}
\hline Tank \# & $\begin{array}{l}\text { Waste } \\
\text { (01d) }\end{array}$ & $\begin{array}{l}1 \text { Type } \\
\text { (New) }\end{array}$ & \multicolumn{2}{|c|}{$\begin{array}{l}\text { Use Designation } \\
\text { (01d (New) }\end{array}$} \\
\hline $\begin{array}{l}104-A N \\
105-A N \\
106-A N \\
107-A N\end{array}$ & $\begin{array}{l}\text { SRCVR } \\
\text { SRCVR } \\
\text { SRCVR } \\
\text { SRCVR }\end{array}$ & $\begin{array}{l}\text { CWHT } \\
\text { CWHT } \\
\text { CWHT } \\
\text { CWHT }\end{array}$ & $\begin{array}{l}\text { DSSF } \\
\text { DSSF } \\
\text { CHFW } \\
\text { CC }\end{array}$ & $\begin{array}{l}\text { DSSF } \\
\text { DSSF } \\
\text { CP } \\
\text { CC }\end{array}$ \\
\hline $\begin{array}{l}101-A P \\
102-A P \\
103-A P \\
104-A P \\
105-A P \\
106-A P \\
107-A P \\
108-A P\end{array}$ & $\begin{array}{l}\text { WRCVR } \\
\text { WRCVR } \\
\text { WRCVR } \\
\text { WRCVR } \\
\text { WRCVR } \\
\text { WRCVR } \\
\text { SRCVR } \\
\text { SRCVR }\end{array}$ & $\begin{array}{l}\text { DRCVR } \\
\text { GRTFD } \\
\text { DRCVR } \\
\text { GRTFD } \\
\text { CWHT } \\
\text { DRCVR } \\
\text { DRCVR } \\
\text { DRCVR }\end{array}$ & $\begin{array}{l}\text { NCPLXX } \\
\text { HFW } \\
\text { NCPLX } \\
\text { HFW } \\
\text { DSSF } \\
\text { NCPLX } \\
\text { NCPLLX } \\
\text { NCPLX }\end{array}$ & $\begin{array}{l}\text { DN } \\
\text { DN } \\
\text { DN } \\
\text { DN } \\
\text { DSSF } \\
\text { DN } \\
D N \\
D N\end{array}$ \\
\hline $\begin{array}{l}101-A W \\
102-A W \\
103-A W \\
104-A W \\
105-A W \\
106-A W \\
101-A Y \\
102-A Y \\
101-A Z \\
102-A Z\end{array}$ & $\begin{array}{l}\text { SRCVR } \\
\text { EVFD } \\
\text { WRCVR } \\
\text { WRCVR } \\
\text { WRCVR } \\
\text { SRCVR } \\
\text { WRCVR } \\
\text { WRCVR } \\
\text { WRCVR } \\
\text { WRCVR }\end{array}$ & $\begin{array}{l}\text { CWHT } \\
\text { EVFD } \\
\text { DRCVR } \\
\text { DRCVR } \\
\text { DRCVR } \\
\text { SRCVR } \\
\text { DRCVR } \\
\text { DRCVR } \\
\text { CWHT } \\
\text { DRCVR }\end{array}$ & $\begin{array}{l}\text { DSSF } \\
\text { NCPLX } \\
\text { NCPLX } \\
\text { NCPLX } \\
\text { NCPLX } \\
\text { DSSF } \\
\text { CPLX } \\
\text { NCPLX } \\
\text { AGING } \\
\text { AGING }\end{array}$ & $\begin{array}{l}\text { DSSF } \\
D N \\
D N / P D \\
D N \\
D N / P D \\
D N \\
D C \\
D N \\
\text { AGINC } \\
\text { AGINC }\end{array}$ \\
\hline $\begin{array}{l}101-S Y \\
102-S Y \\
103-S Y\end{array}$ & $\begin{array}{l}\text { DSSHT } \\
\text { WRCVR } \\
\text { SRCVR }\end{array}$ & $\begin{array}{l}\text { CWHT } \\
\text { DRCVR } \\
\text { CWHT }\end{array}$ & $\begin{array}{l}\text { CC } \\
\text { NCPLX } \\
\text { CC }\end{array}$ & $\begin{array}{l}C C \\
D N / P 1 \\
C C\end{array}$ \\
\hline
\end{tabular}

2) Appendix B. Monthly Summary

a) Inventory Summary by Tank Farm

This section has been revised to incorporate the changes in Appendix A, Tank Equipment Code and Status Definitions.

b) Inventory and Status by Tank

The Waste Material and Tank Use columns in the Double-She 11 Tank section have been revised to incorporate the changes in Appendix A, Tank Equipment Code and Status Definitions.

3) Appendix C. Performance Summary

The categories in the Waste Generated section of this appendix have been revised to more accurately depict the source of the waste. 


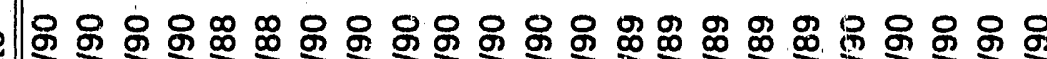

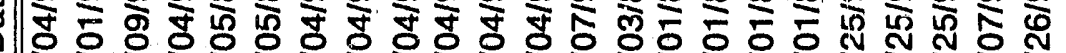

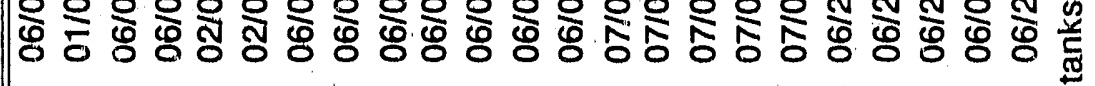

융

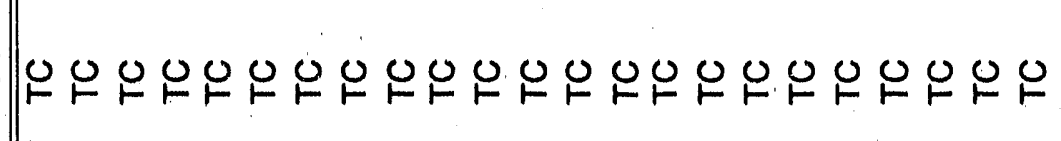

E

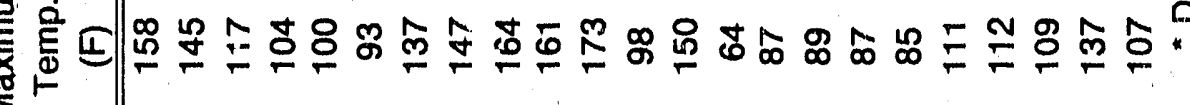

占

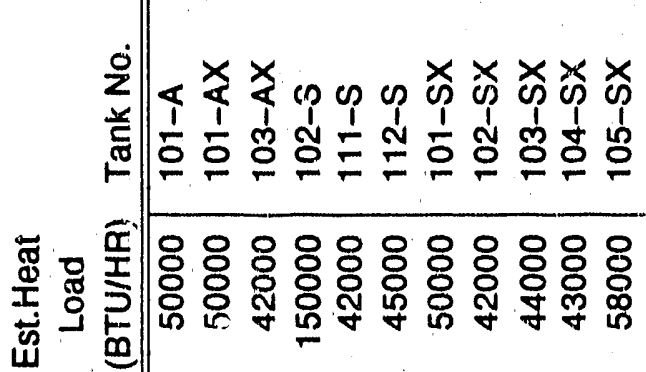

势

岁

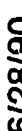

용ㅇㅇㅇㅇㅇㅇㅇㅇㅇㅇㅇㅇㅇ

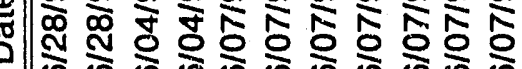

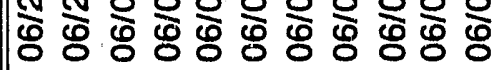

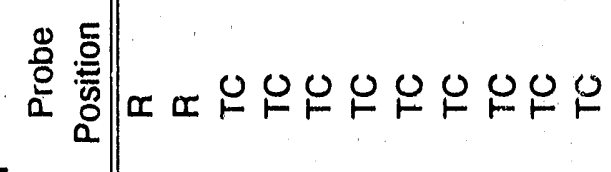

E

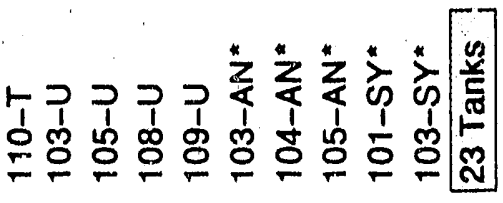

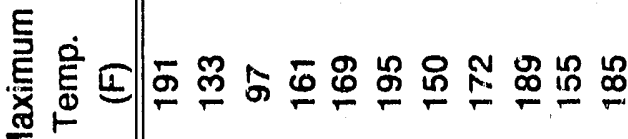

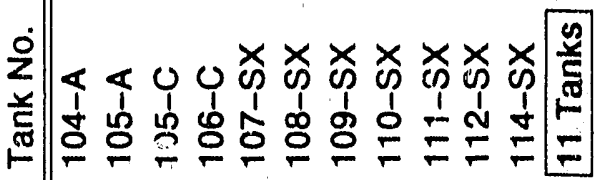

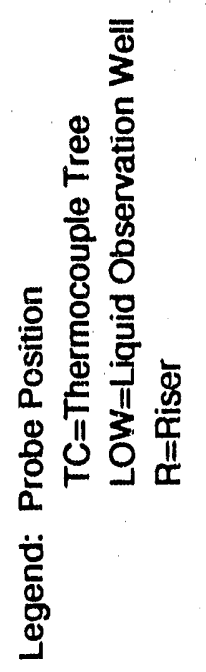

ตัติ ส্

ลิ ลิ

I

峳

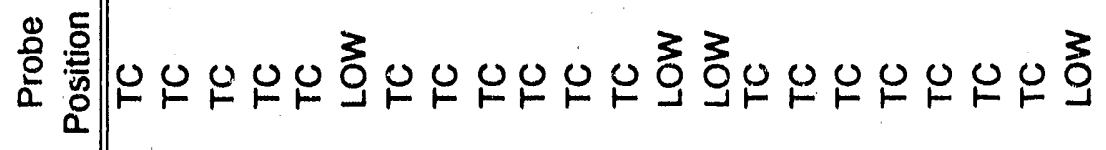

:

E

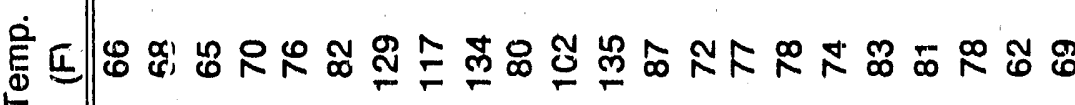

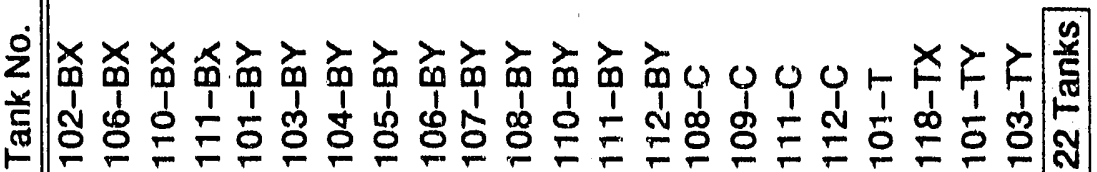


Figure 1. Tank 101-SY Surface Level Readings.

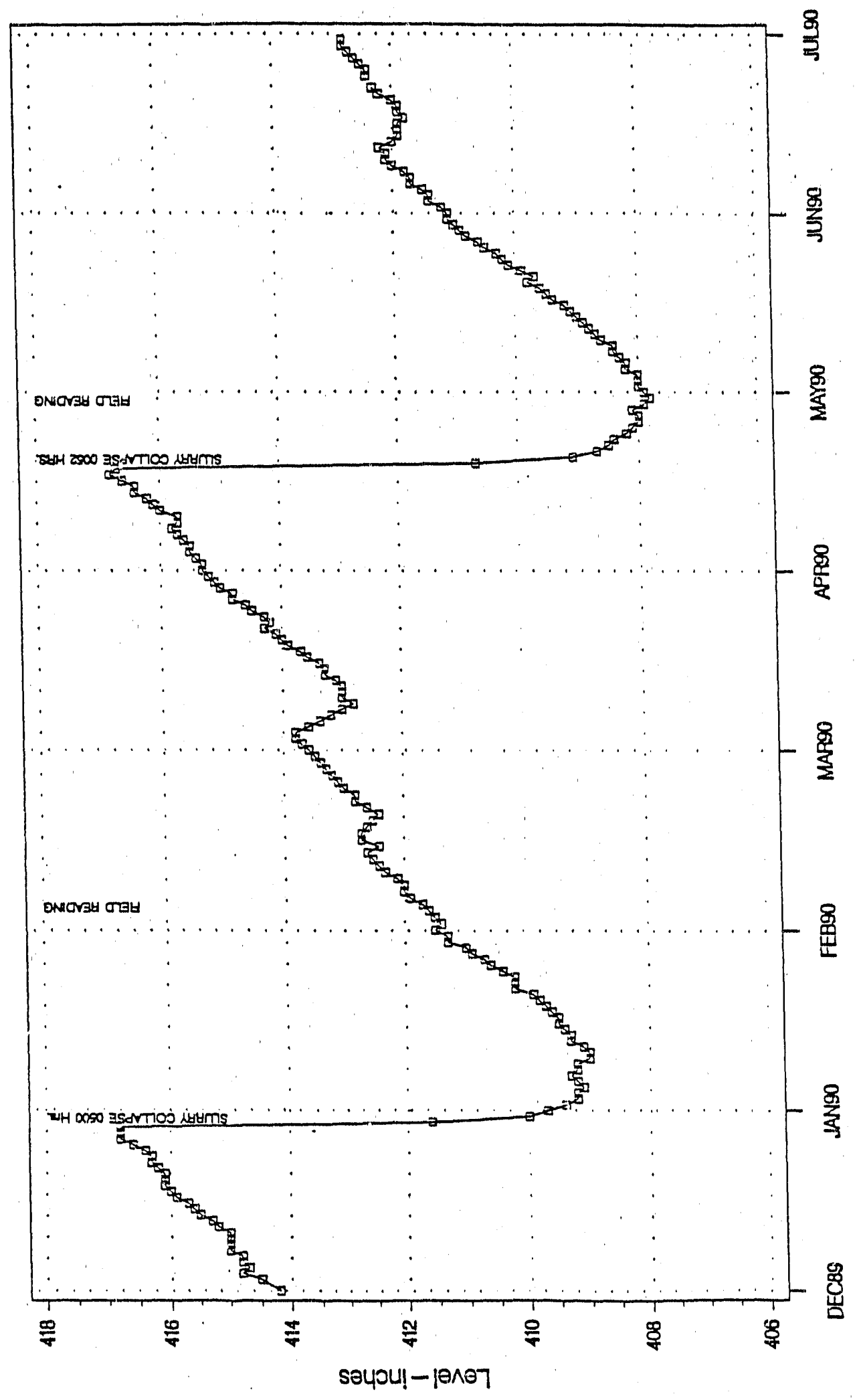


WHC-EP-0182-27

APPENDIX A

TANK AND EQUIPMENT CODE AND STATUS DEFINITIONS

A-1/2 
TANK AND EQUIPHENT CODE/STATUS DEFINITIONS

\section{TANK STATUS CODES}

\section{WASTE TYPE}

$\begin{array}{ll}\text { AGING } & \text { Aging Waste } \\ \text { CC } & \text { Complexant Concentrate Waste } \\ \text { CP } & \text { Concentrated Phosphate Waste } \\ \text { CPLX } & \text { Complexed Waste } \\ \text { DC } & \text { Dilute Complexed Waste } \\ \text { DN } & \text { Dilute Non-Complexed Waste } \\ \text { DSS } & \text { Double-She11 Slurry } \\ \text { DSSF } & \text { Double-Shell Slurry Feed } \\ \text { NCPLX } & \text { Non-Complexed Waste } \\ \text { PD } & \text { PUREX Decladding Solids (TRU) } \\ \text { PT } & \text { PFP TRU Solids }\end{array}$

IANK USE (DOUBLE-SHELL TANKS ONLY)

CWHT Concentrated Waste Holding Tank

DRCVR Dilute Receiver Tank

EVFD Evaporate Feed Tank

GRTFD Grout Feed Tank

SRCVR Slurry Receiver Tank

2. SOLID AND LIOUID VOLUME DETERMINATION METHODS

$\begin{array}{ll}\text { F } & \text { FIC Automatic Surface Level Gauge } \\ M & \text { Marual Tape Surface Level Gauge } \\ \text { P } & \text { Photo Evaluation } \\ \text { S } & \text { Solids Level }\end{array}$

\section{DEFINITIONS}

\section{WASTE TYPES}

Aging Waste

(AGING)

Concentrated

Complexant (CC)

High level, first cycle solvent extraction waste from PUREX.

Concentrated

Phosphate Waste (CP)

Concentrated product from the evaporation of dilute complexed waste.

Waste originating from the decontamination of $100-\mathrm{N}$ Area reactor. This waste is diluted to form dilute phosphate waste.

Complexed Waste (CPLX)

Dilute waste material containing relatively high concentrations of chelating agents, such as EDTA, HEDTA, from B Plant waste fractionization operation. 
Dilute Complexed Waste (DC)
Characterized by a high content of organic carbon including organic complexants: EDTA, citric acid, HEDTA, IDA being the major complexants used. Main sources of DC waste are saltwell liquid inventory.

Dilute Non-Complexed

Waste (DN)

Double-shei:

STurry (DSS)

Double-Shel1

Slurry Feed (DSSF)

Non-complexed

(NC,PLX)

PUREX Decladding $(P D / P N)$

PFP TRU Solids

(PT)

Drainable

Interstitial

Liquid (DIL)

Supernatant

\section{WASTE STATUS}

In-Service Tank

Out-of-Service

Tank
Low activity liquid waste originating from $T$ and $S$ Plants, the 300 and 400 Areas, PUREX facility (decladding supernate, and miscellaneous wastes), 100-N Area (sulfate waste, B Plant, saltwells, and PFP (supernate).

Waste evaporated just past its sodium aluminate saturation boundary or 6.5 moiar hydroxide in the evaporator. For reporting purposes, DSS is considered a solid.

Waste evaporated just before reaching the sodium aluminate saturation boundary or $6.5 \mathrm{molar}$ hydroxide in the evaporator. This form is not as concentrated as double-shell slurry.

General waste term applied to all Hanford 1 iquors not identified as complexed.

PUREX Neutralized Cladding Removal Waste (NCRW) is the solids portion of the PUREX Facility neutralized cladding removal waste stream, received in Tank Farms as a slurry. Classified as TRU waste.

TRU solids from West Area operations.

Interstitial Liquid that is not held in place by capillary forces, and will therefore migrate or move by gravity.

The liquid above the solids in waste storage tanks.

The waste classification of a tank being used, or planned for use, for the storage of liquid (in excess of a minimum supernatant liquid hee1) in conjunction with production and/or waste processing.

A tank which does not meet the definition of an inservice tank. Before September 1988, these tanks were defined as inactive in this report. (Note: All Single-Shell tanks are out of service.) 
STABILIZATION (Single-Shell Tanks only)

Interim

Stabilized

(IS)
A tank which contains less than 50,000 gallons of drainable interstitial liquid and less than 5,000 gallons of supernatant liquid.

\section{ISOLATION (Single-Shell Tanks only)}

Partially

Interim Isolated (PI)

Interim Isolated (II)

\section{TANK INTEGRITY}

Sound

Assumed Leaker

Intrusion

\section{TANK INVESTIGATION}

The administrative designation reflecting the completion of the physical effort required for Interim Isolation except for isolation of risers and piping that is required for jet pumping or for other methods of stabilization.

The administrative designation reflecting the completion of the physical effort required to minimize the addition of liquids into an inactive storage tank, process vault, sump, catch tank, or diversion box.

The integrity classification of a waste storage tank for which surveilance data indicates no loss of 1 iquid attributabed to a breach of integrity.

The integrity classification of a waste storage tank for which surviellance data indicates a loss of 1 iquid attributed to a breach of integrity.

A term used to describe the infiltration of liquid into a waste tank.

4. INVENTORY AND STATUS BY TANK - COLUMN CALCULATIONS (SINGLE-SHELL TANKS)

\section{COLUMN HEADING}

Total Waste Solids volume plus Supernatant liquid.

Supernatant Drainable Liquid Remaining minus Drainable Interstitial. Liquid Supernatant is usually derived by subtracting the solids level measurement from the liquid level measurement.

Drainable Interstitial

Drainable Liquid Remaining minus Supernatant.

Drainable Interstitial Liquid is calculated based on the salt cake and sludge volumes, using average porosity values or actual data for each tank, when available.

Total Jet

Pumped

$$
\text { Cumulative total pumped } 1979 \text { to date }
$$


Drainable

Liquid

Remaining

Pumpable

Liquid

Remaining

Sludge

Salt Cake
Supernatant plus Drainable Interstitial.

Drainable Liquid Remaining less undrainable heel volume.

Solids formed during Sodium Hydroxide additions to waste. Sludge usually was in the form of suspended solids when the waste was originally received in the tank by the waste generator. In-tank photographs may be used to estimate the volume.

Results from crystalization and precipitation after concentration of liquid waste, usually in an evaporator. If salt cake is layered over sludge, it is only possible to measure total solids volume. In-tank photographs may be used to estimate the salt cake volume.

Solids Volume Indicates the Tatest update of any change in the solids volume.

Solids Update Source - See Indicates the source or basis of the latest solids Footnote

Last Photo Date of latest in-tank photographs taken.

Date

Change Since Last Monthly Report

Indicates any change made since the previous month. Explanation for the change follows the Inventory and Status by Tank section. 
Figure A-1. Single-Shell Tank Surveillance Instrumentation.

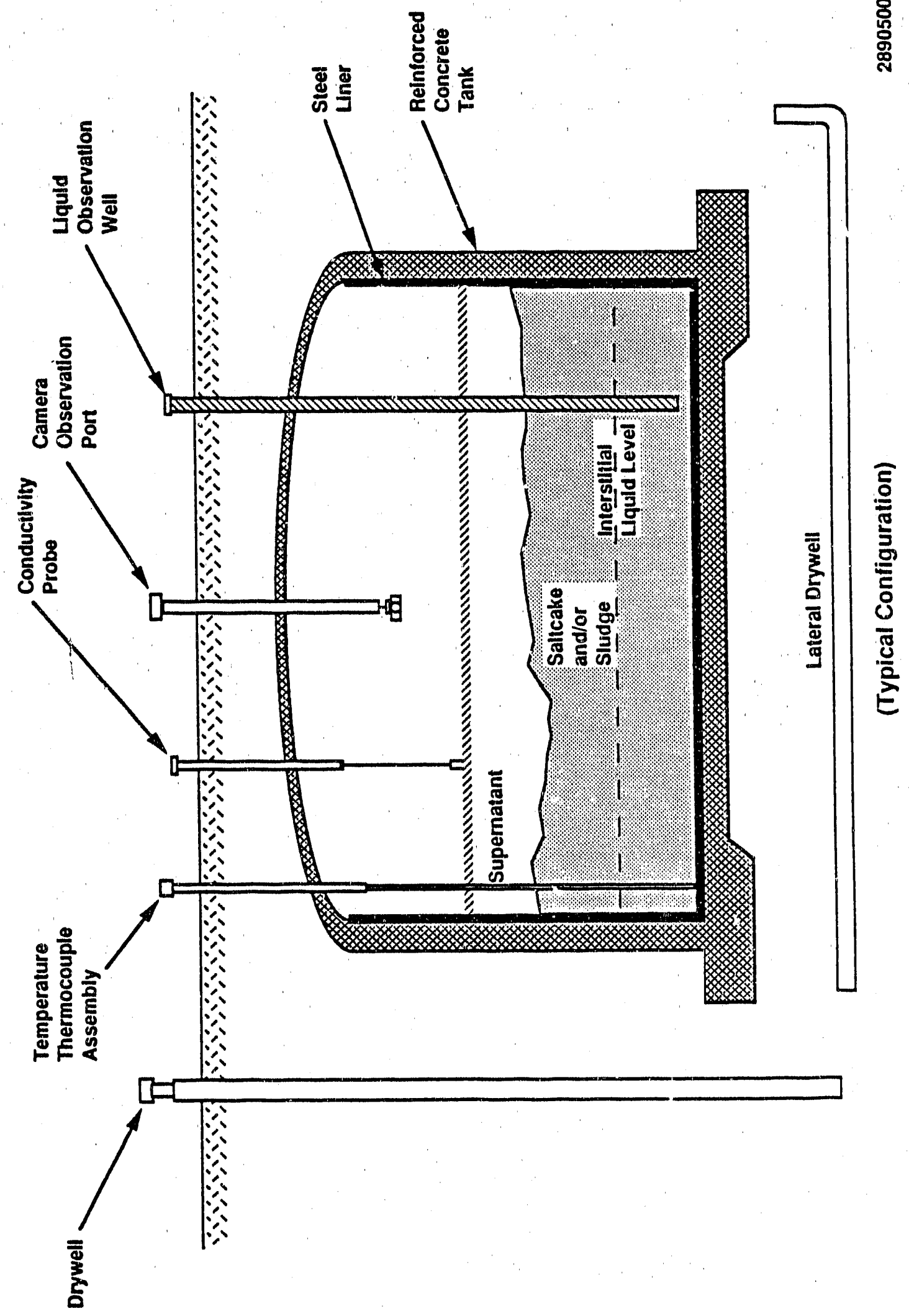


WHC-EP-0182-27

Figure A-2. Double-She11 Tank Surveillance Instrumentation.

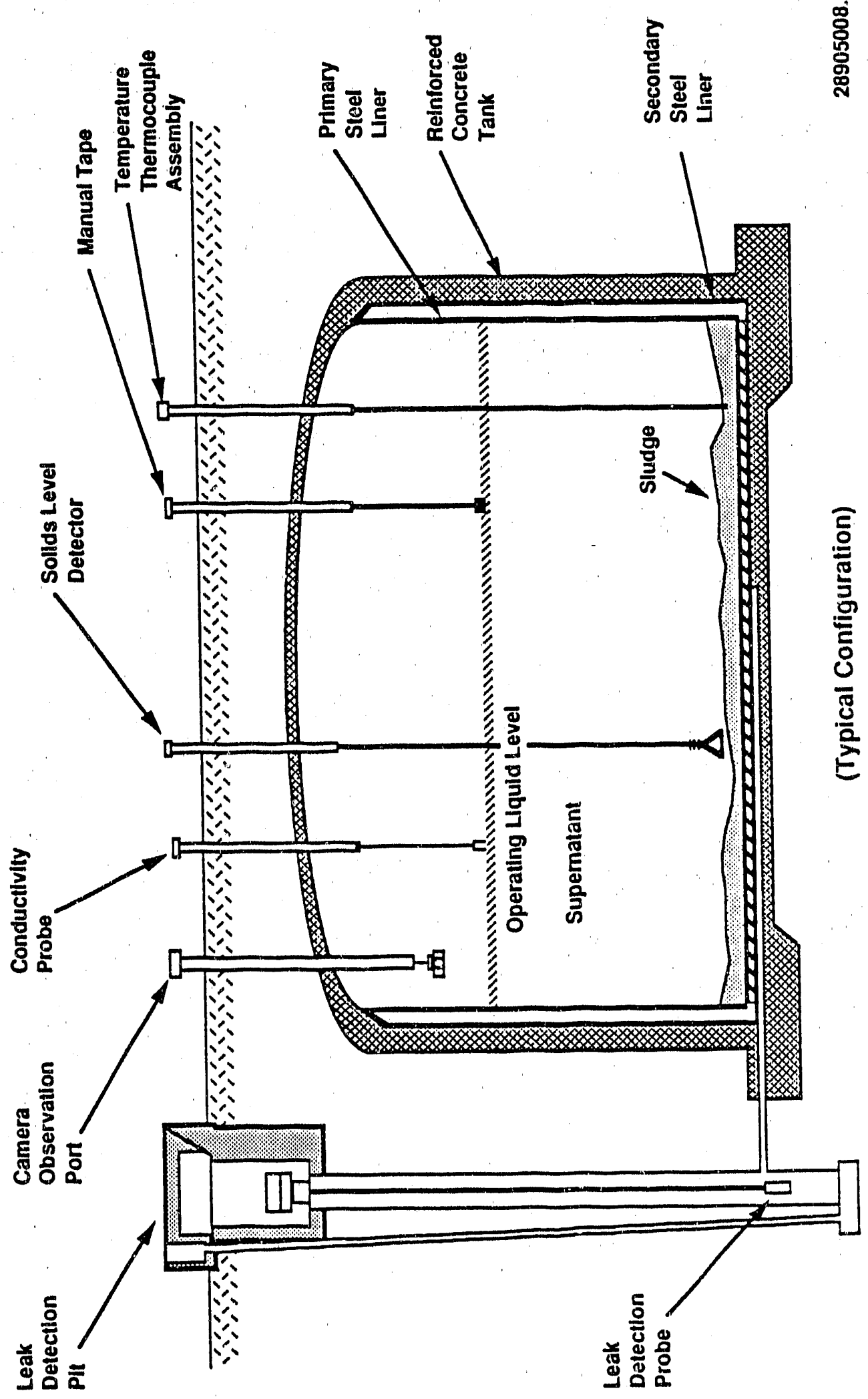




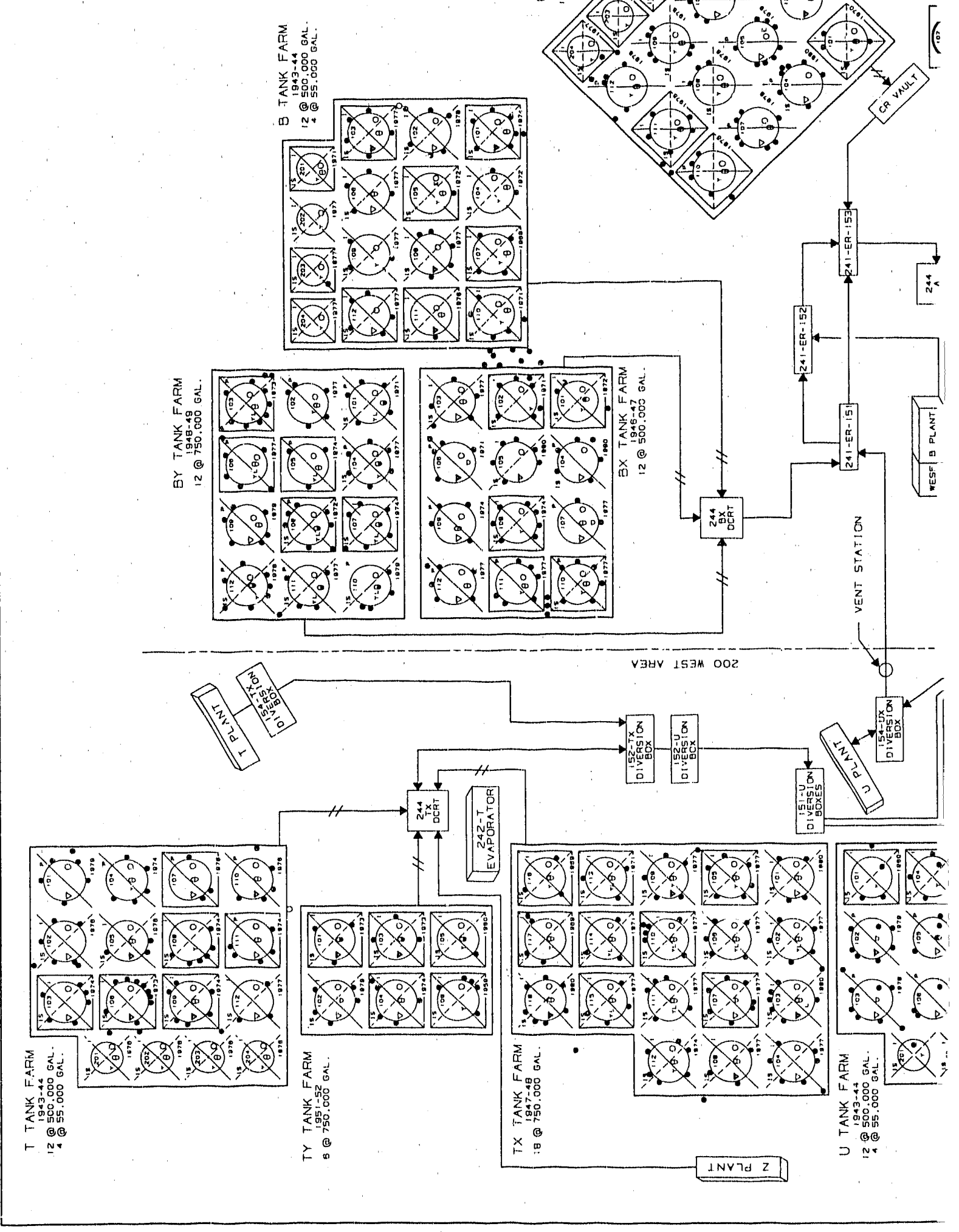




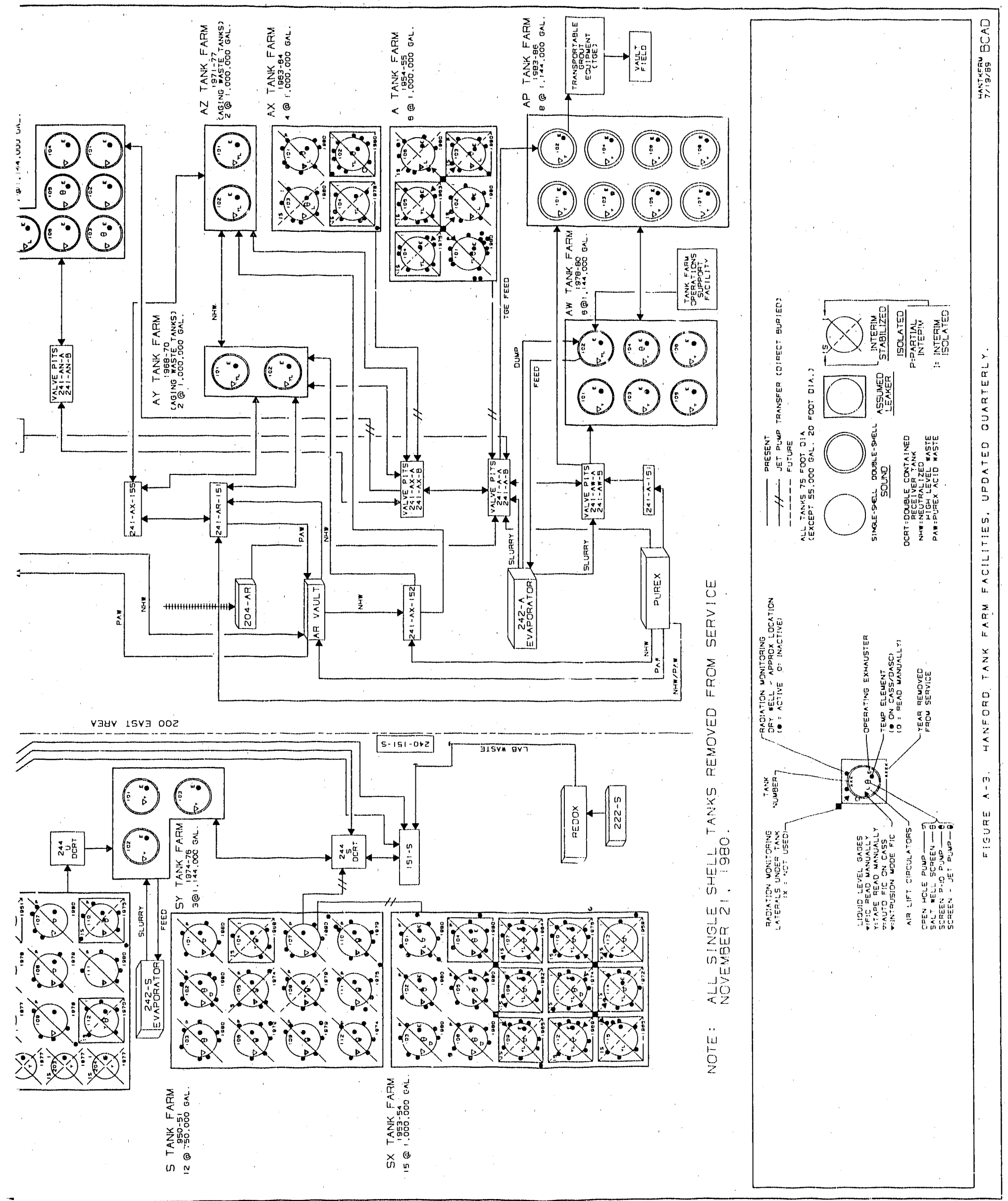


WHC-EP-0182-27

APPENDIX B

MONTHLY SUMMARY

TANK USE SUMMARY

INVENTORY SUMMARY BY TANK FARM

INVENTORY AND STATUS BY TANK

B $-1 / 2$ 


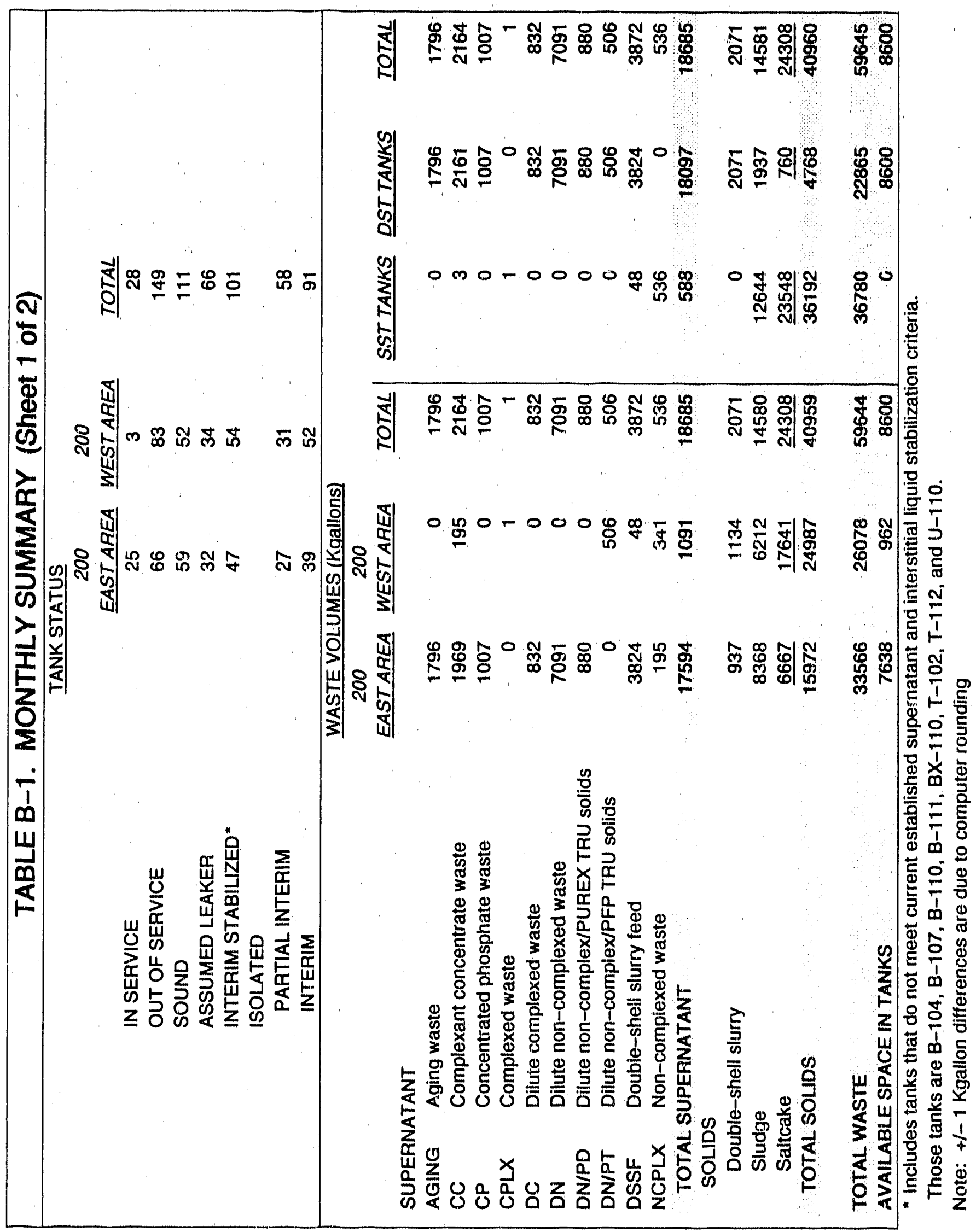




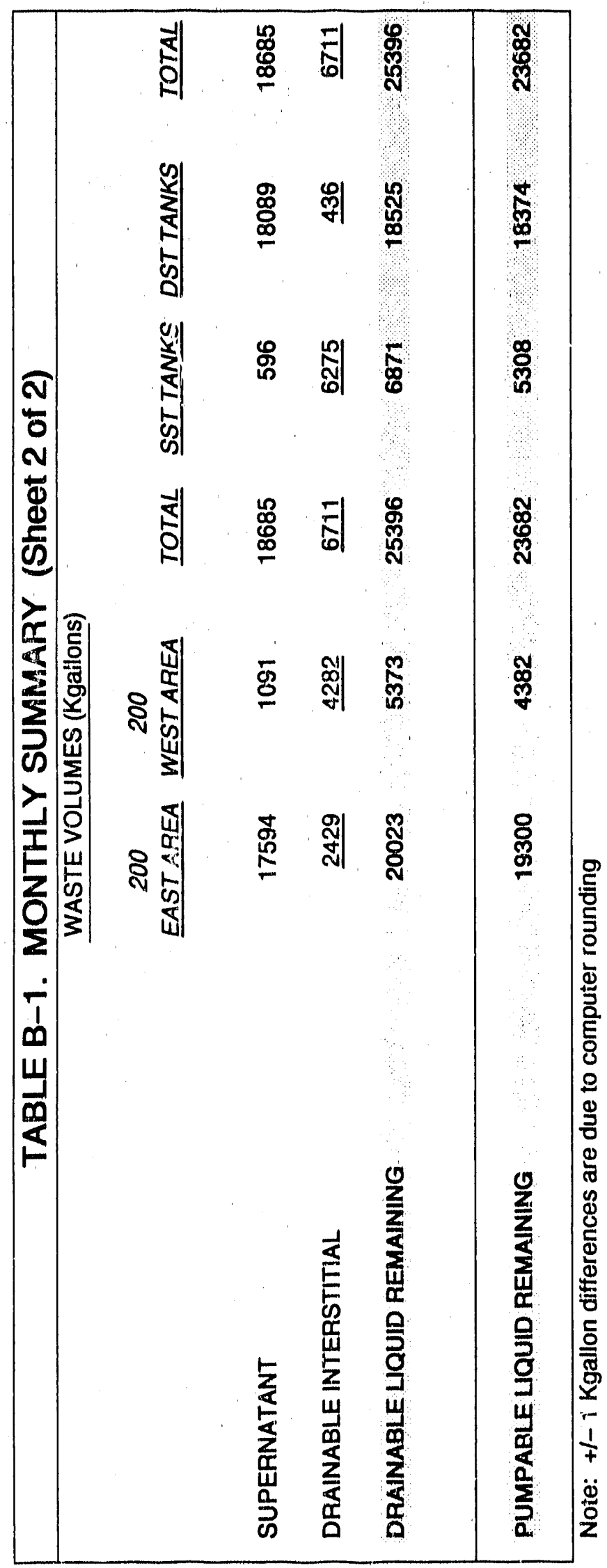


WHC-EP-0172-27

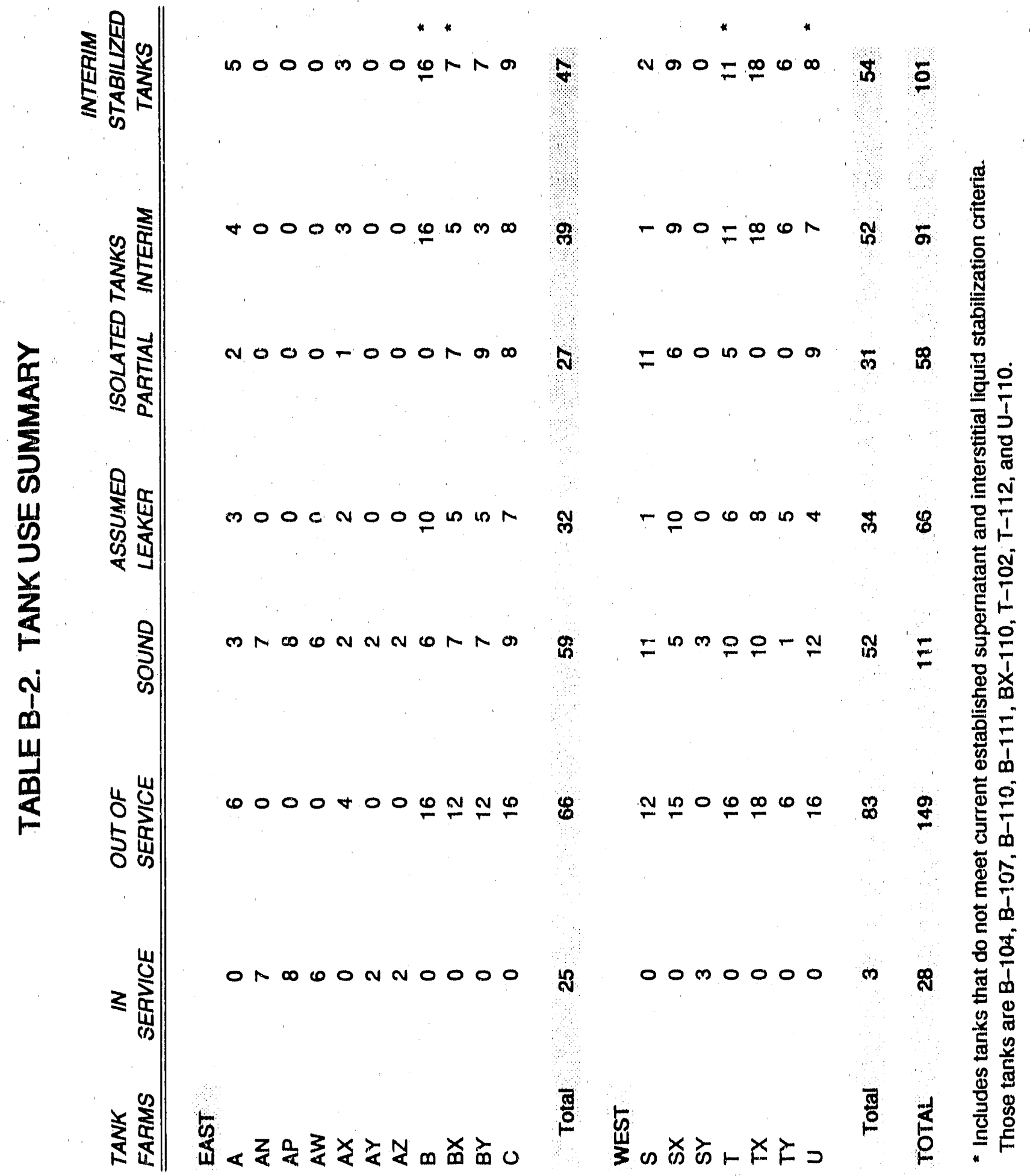




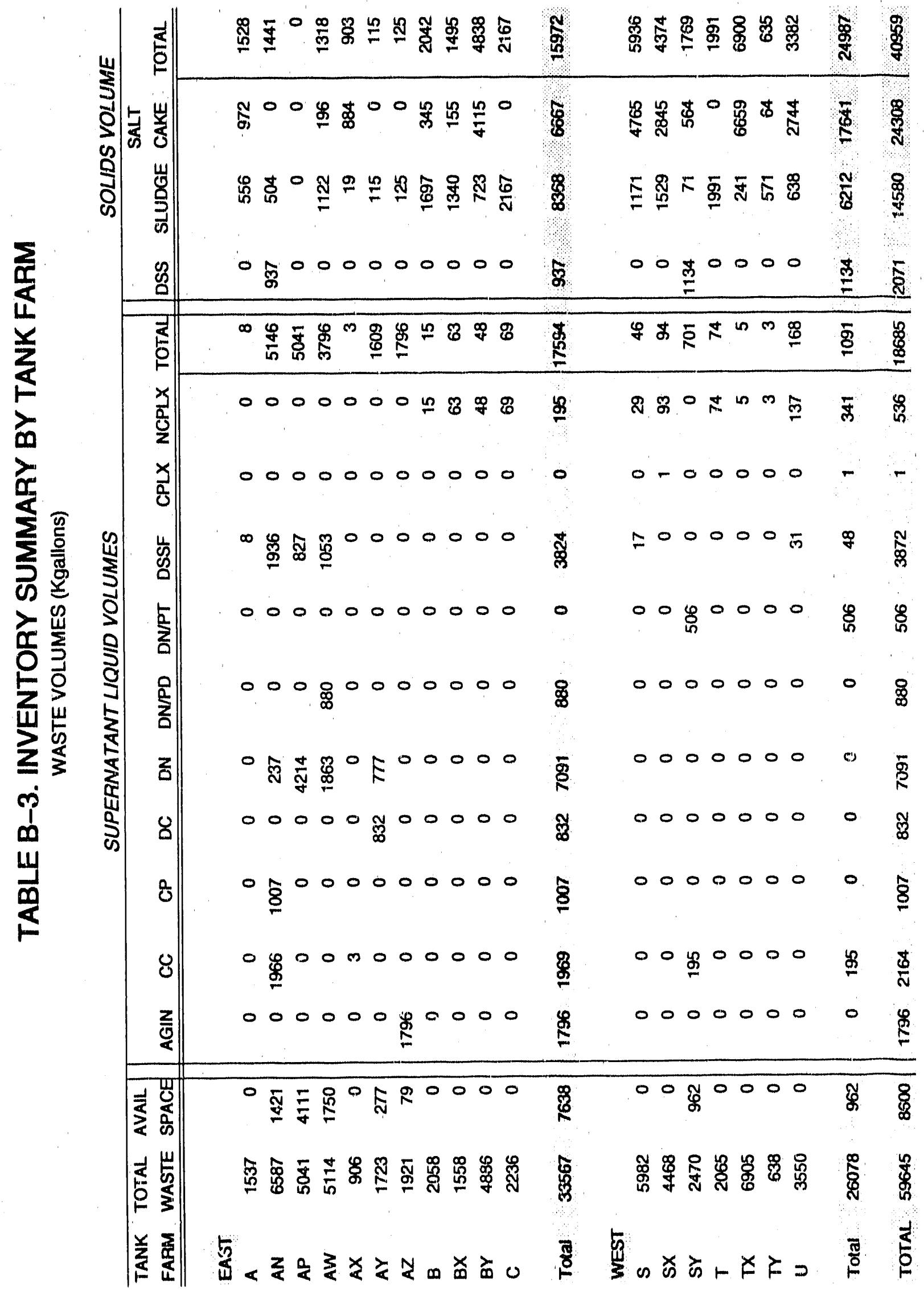




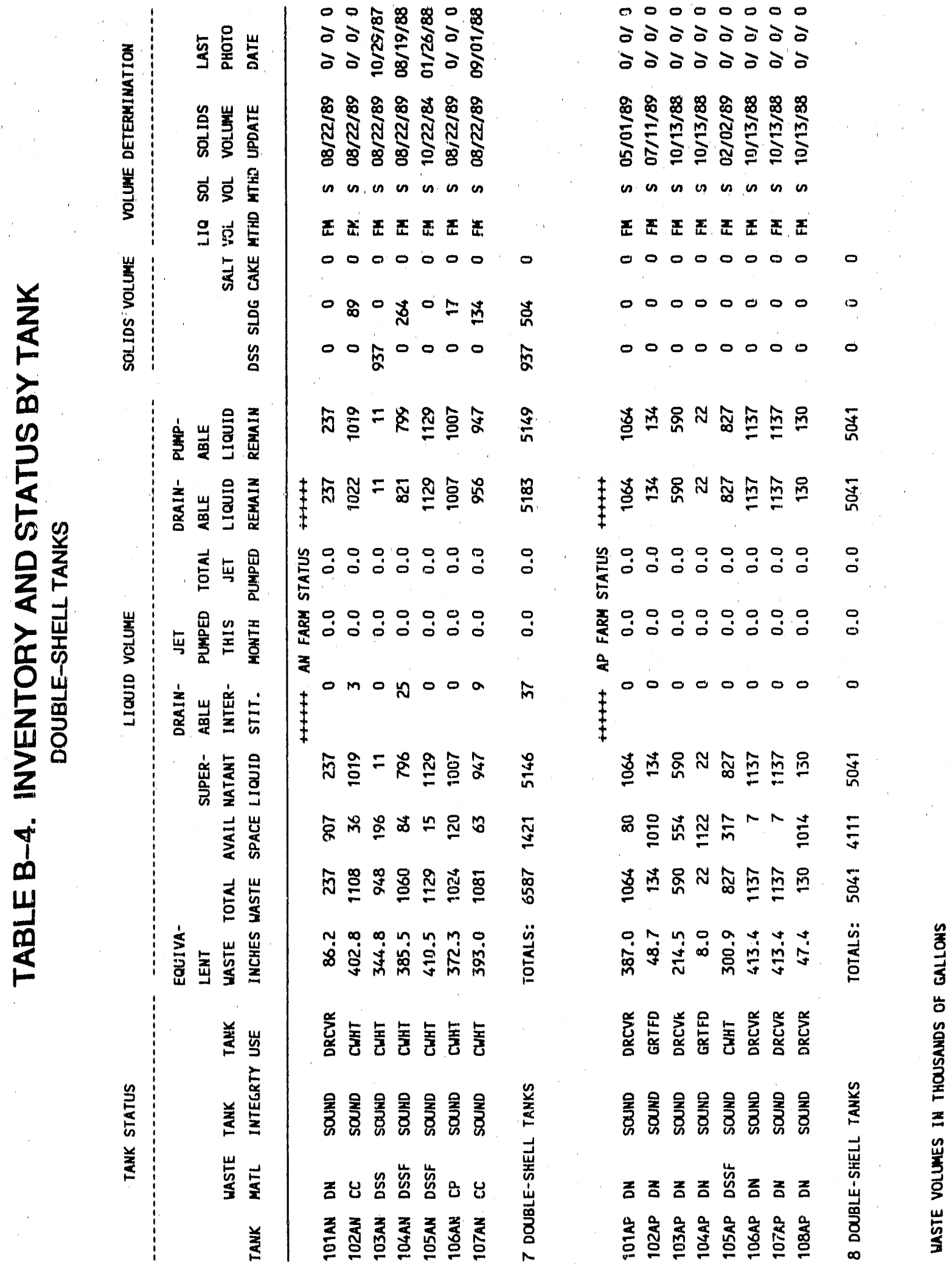




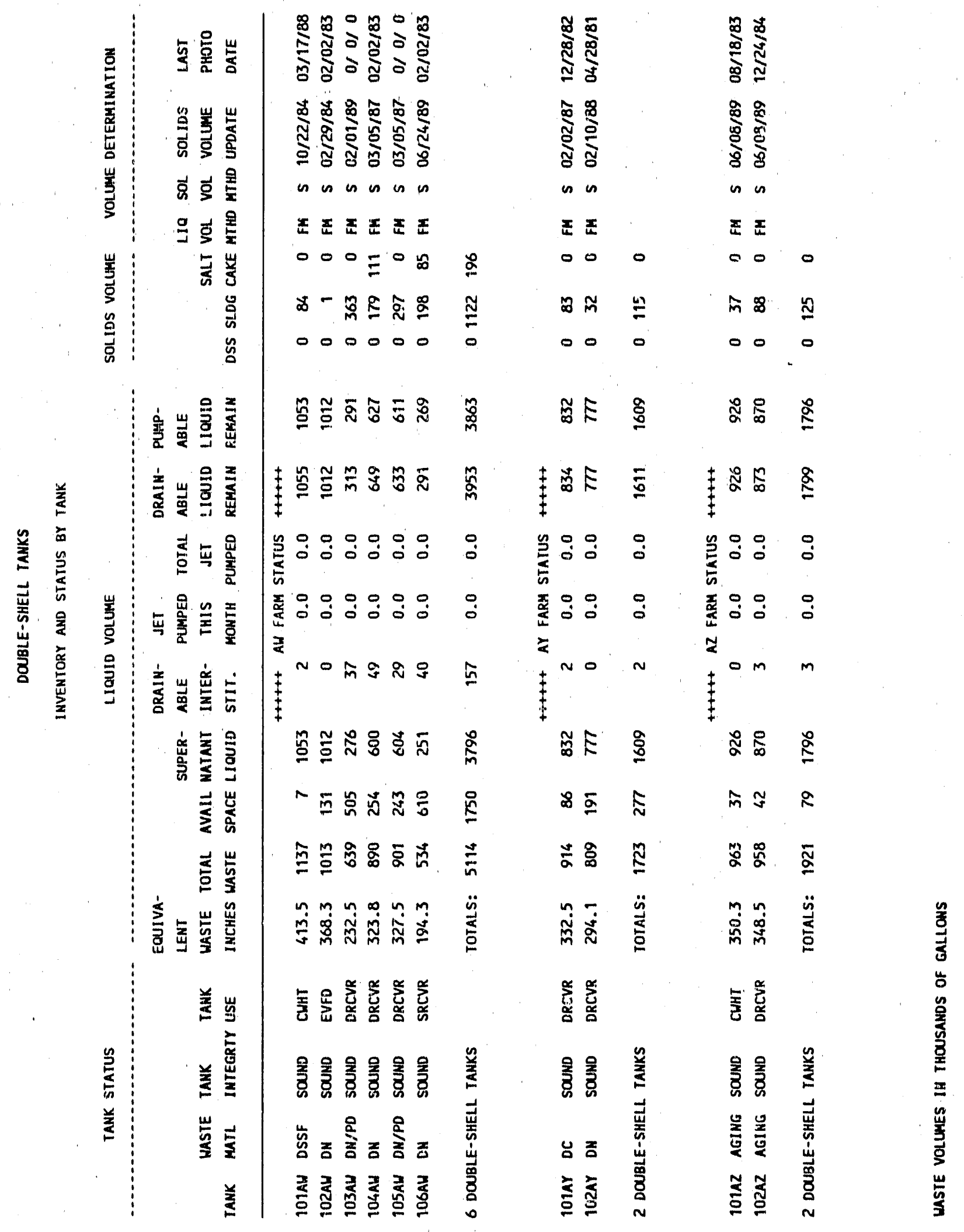




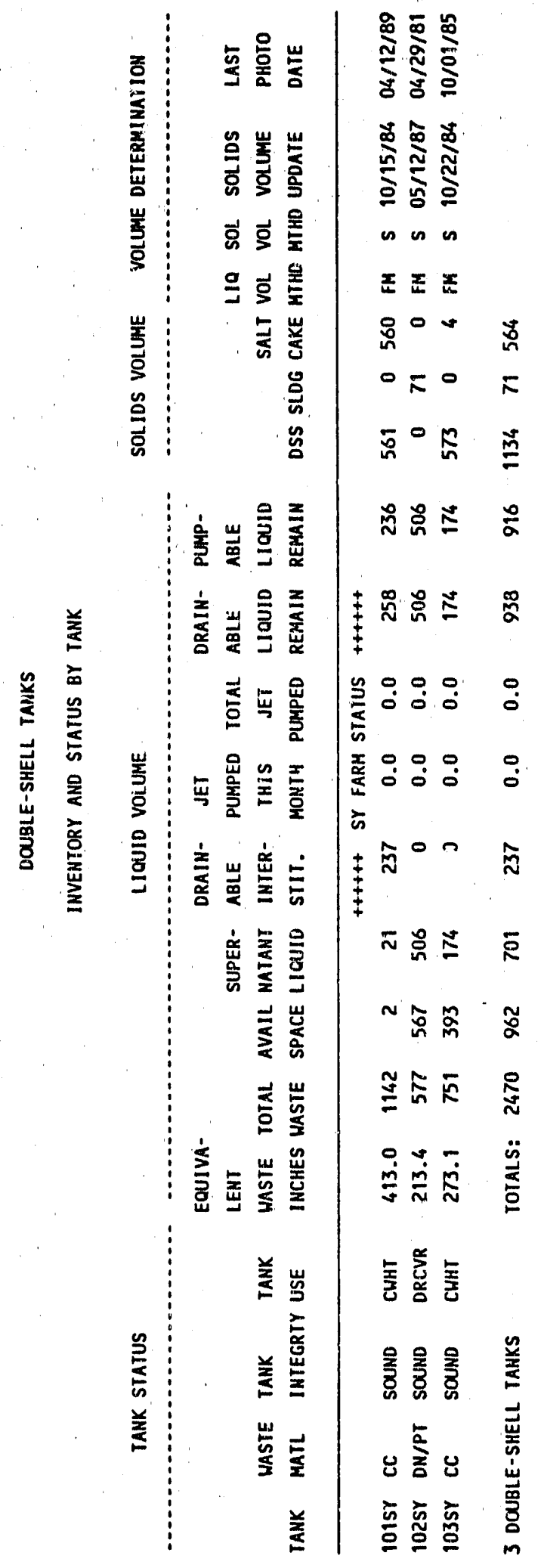




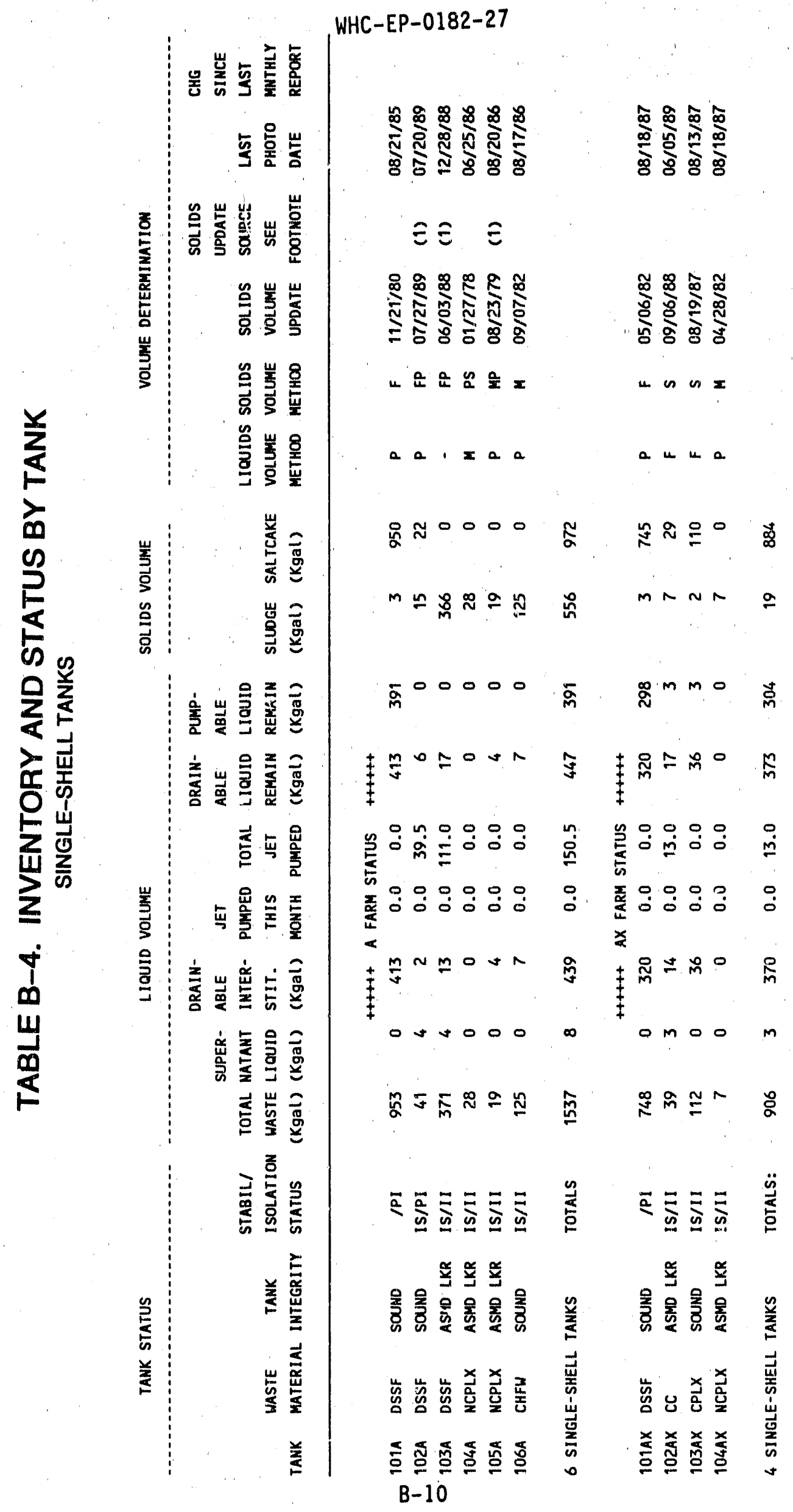




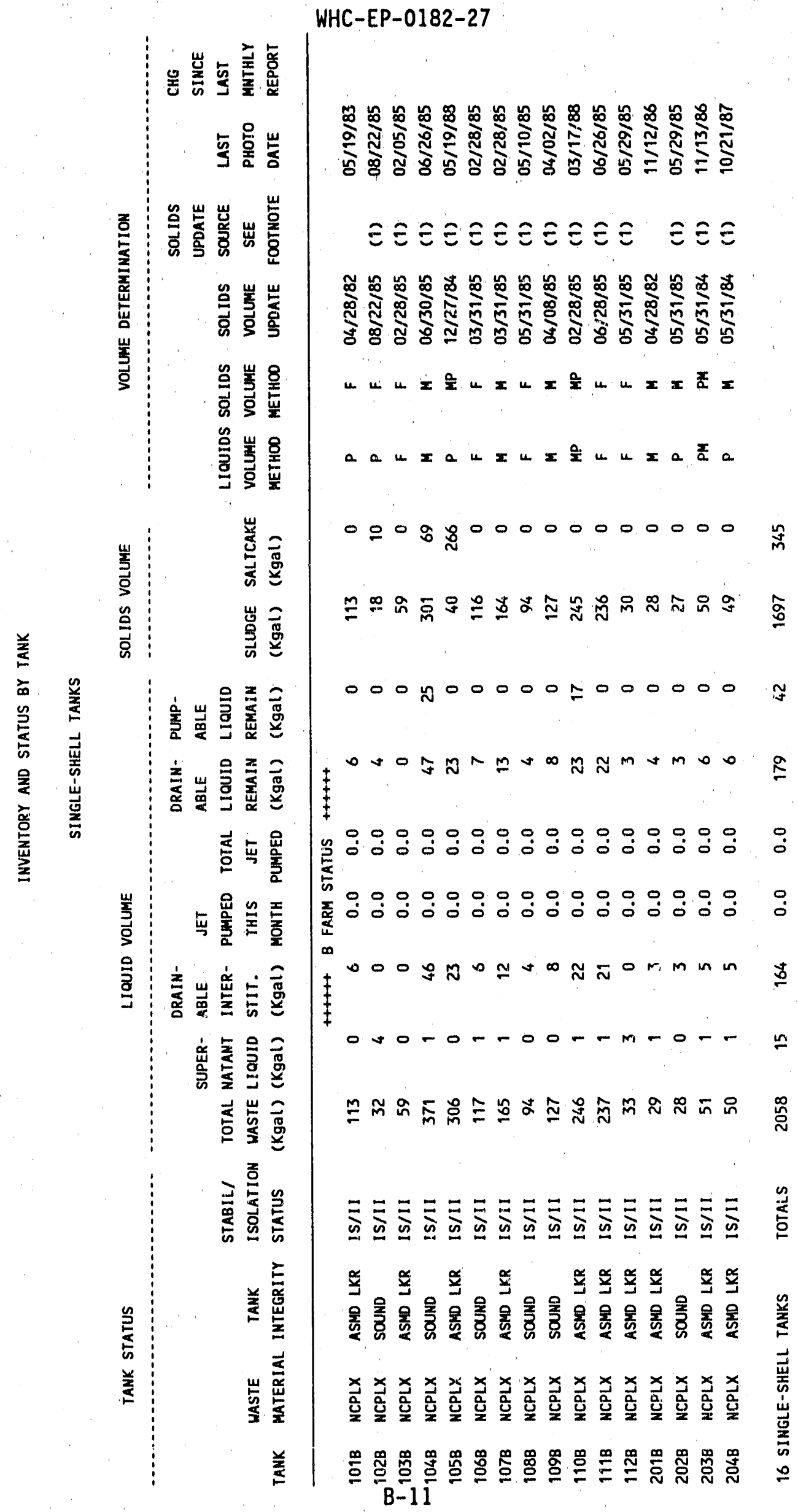




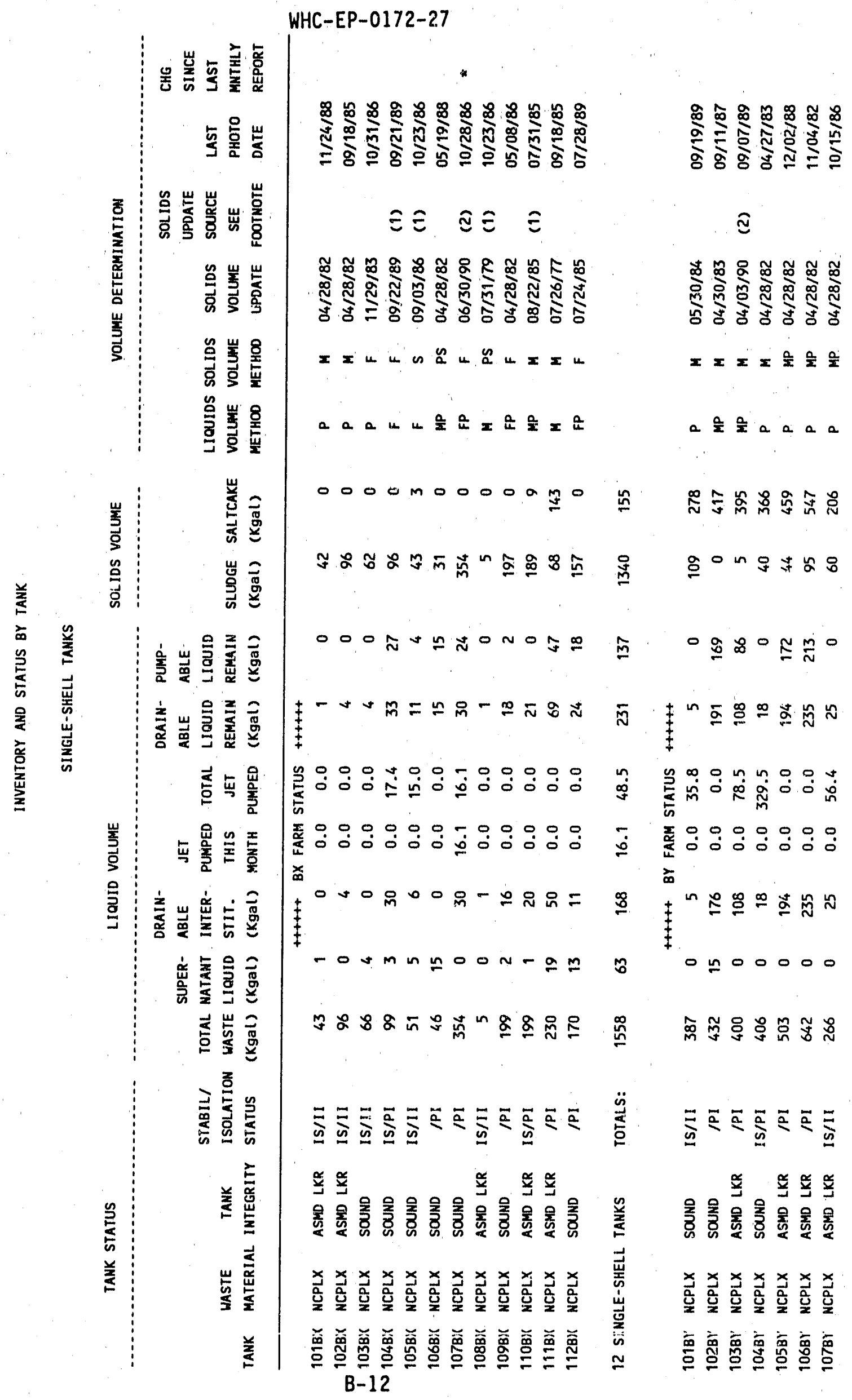




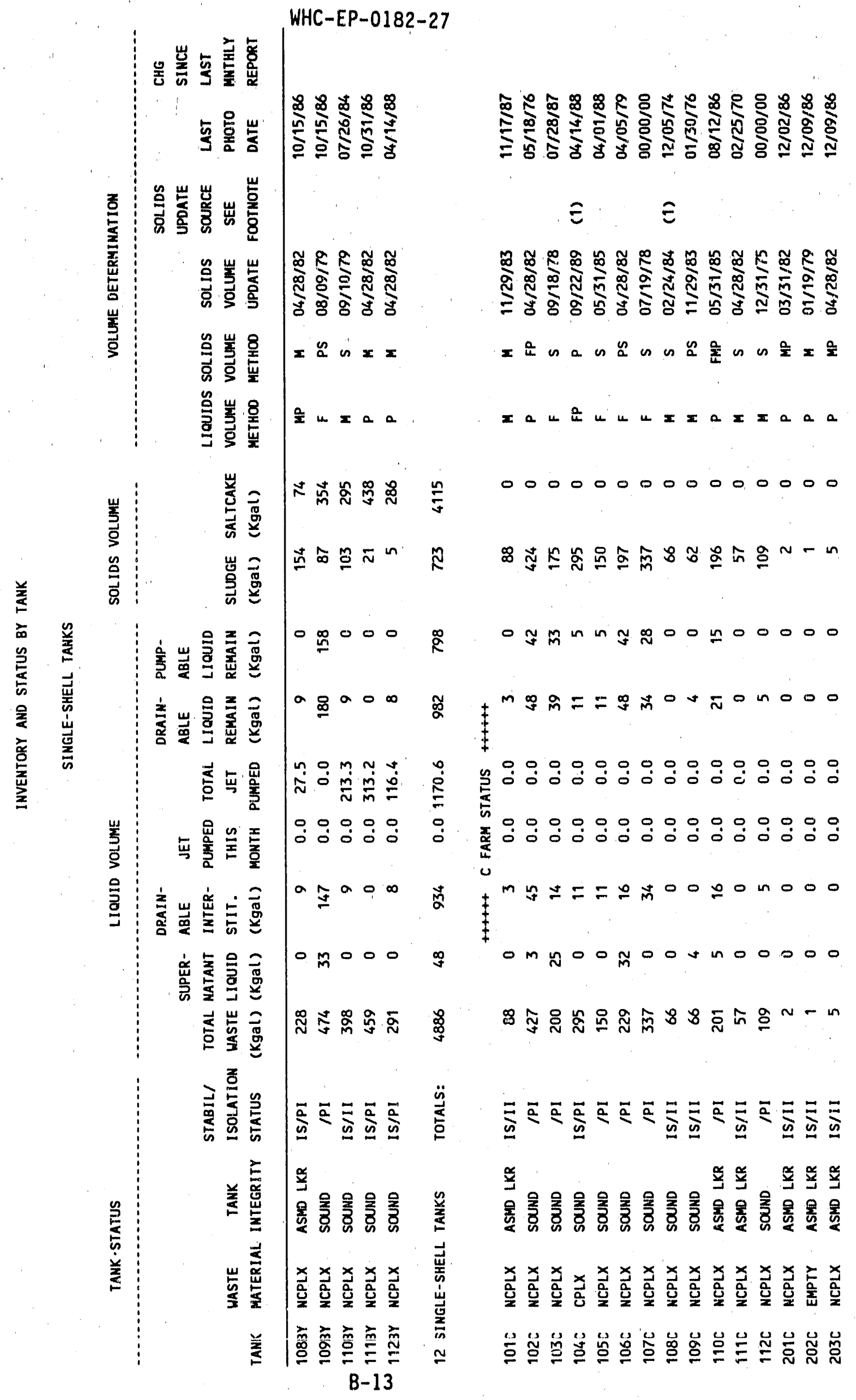




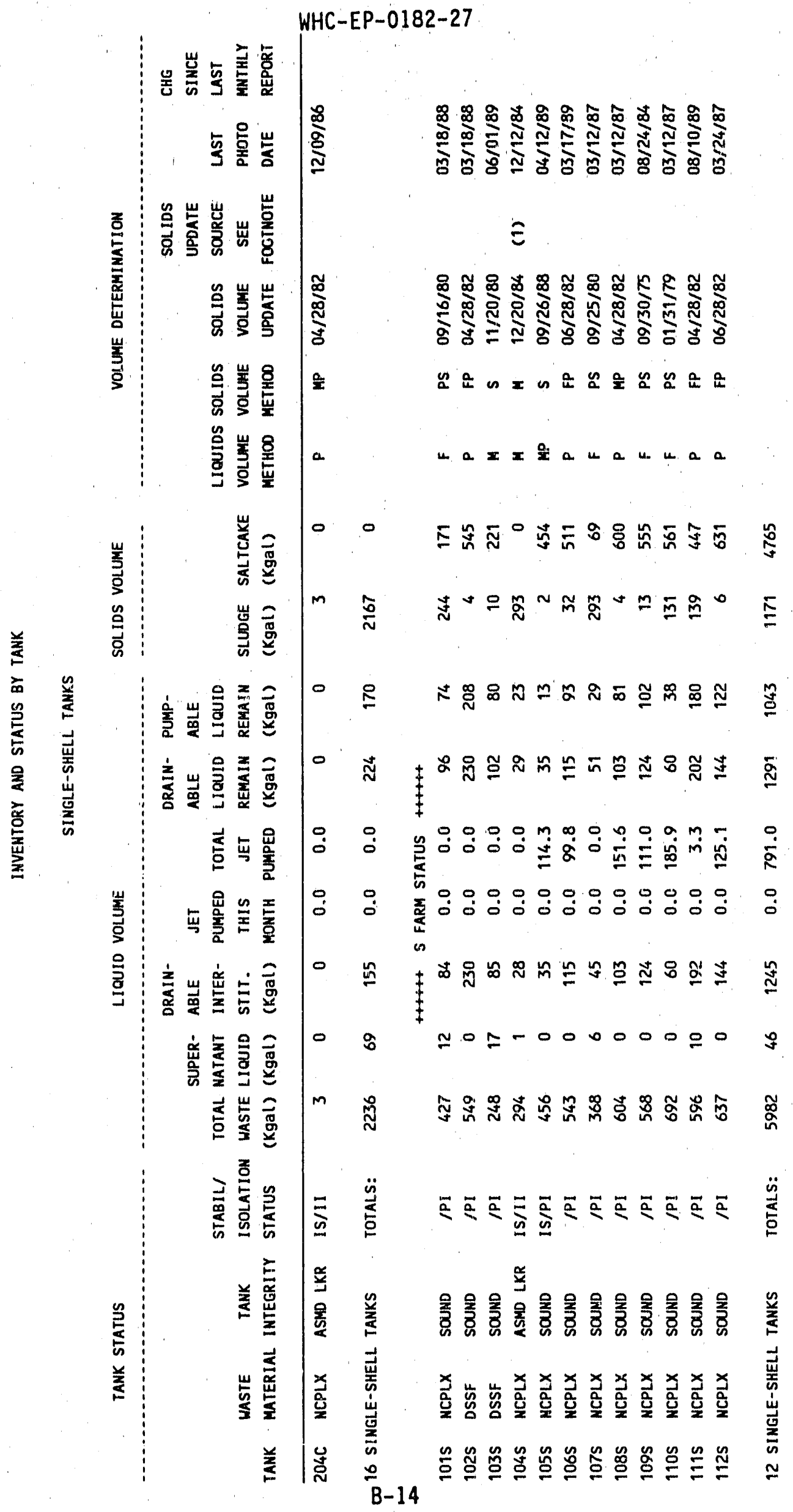




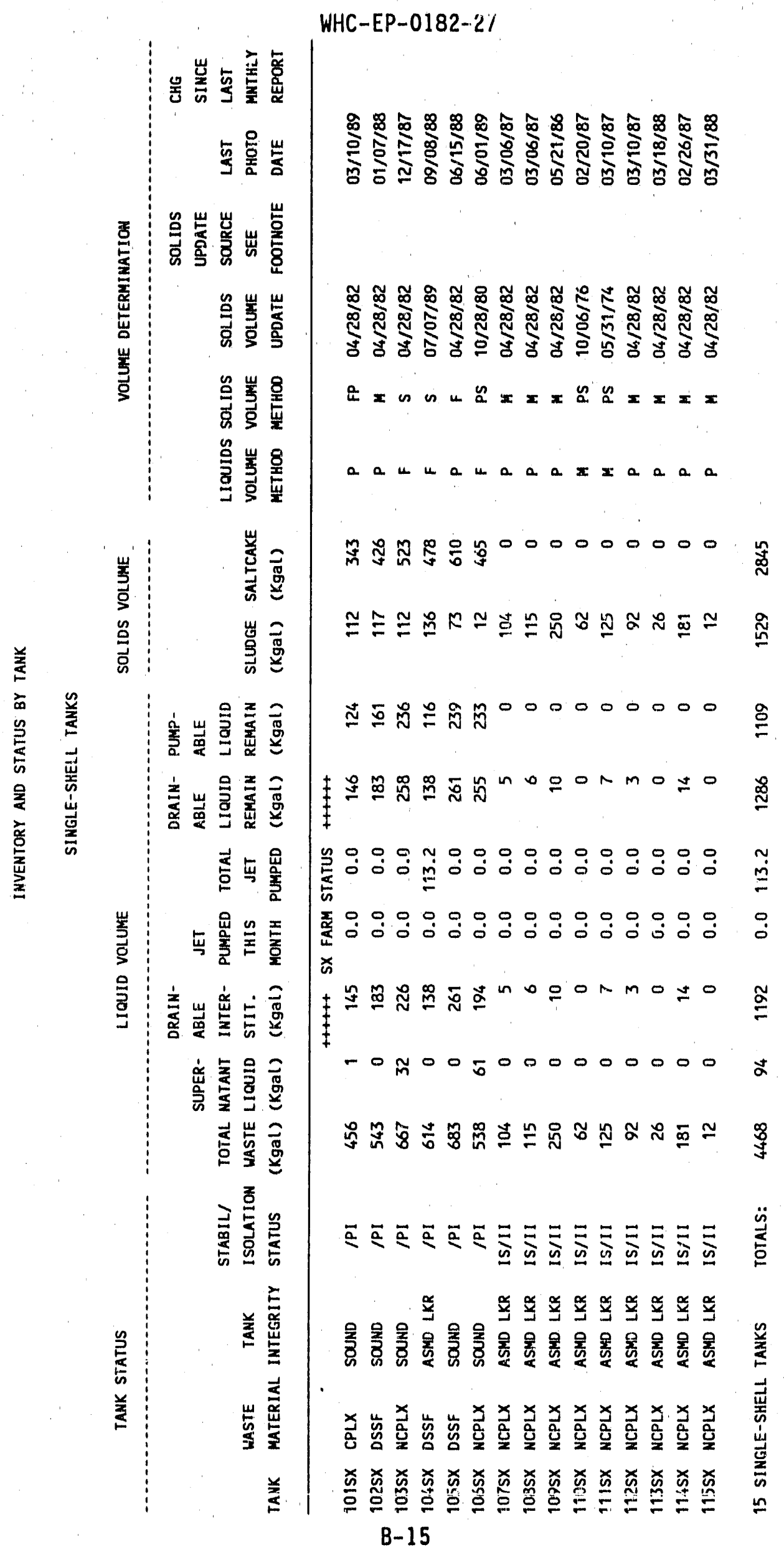




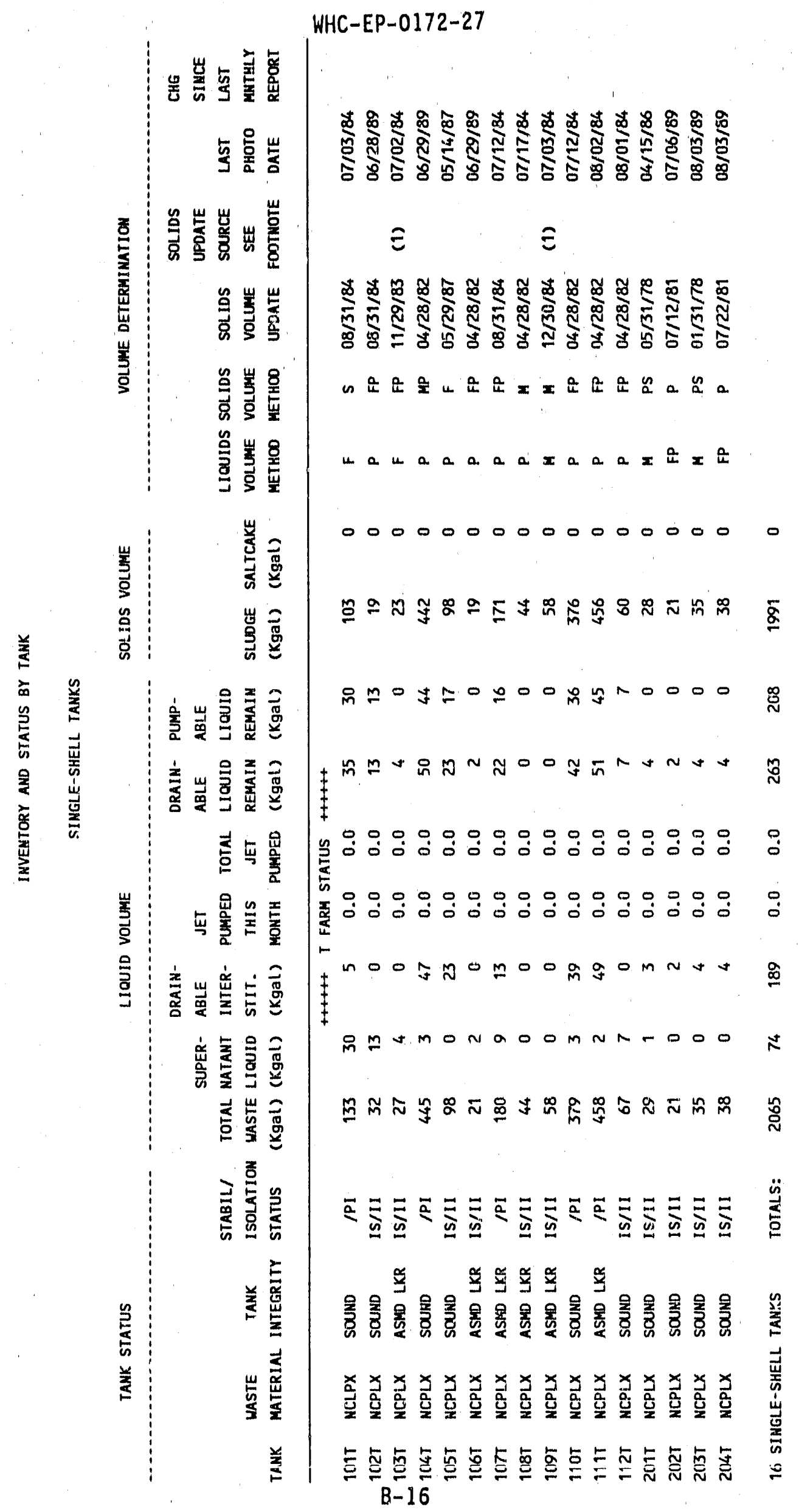




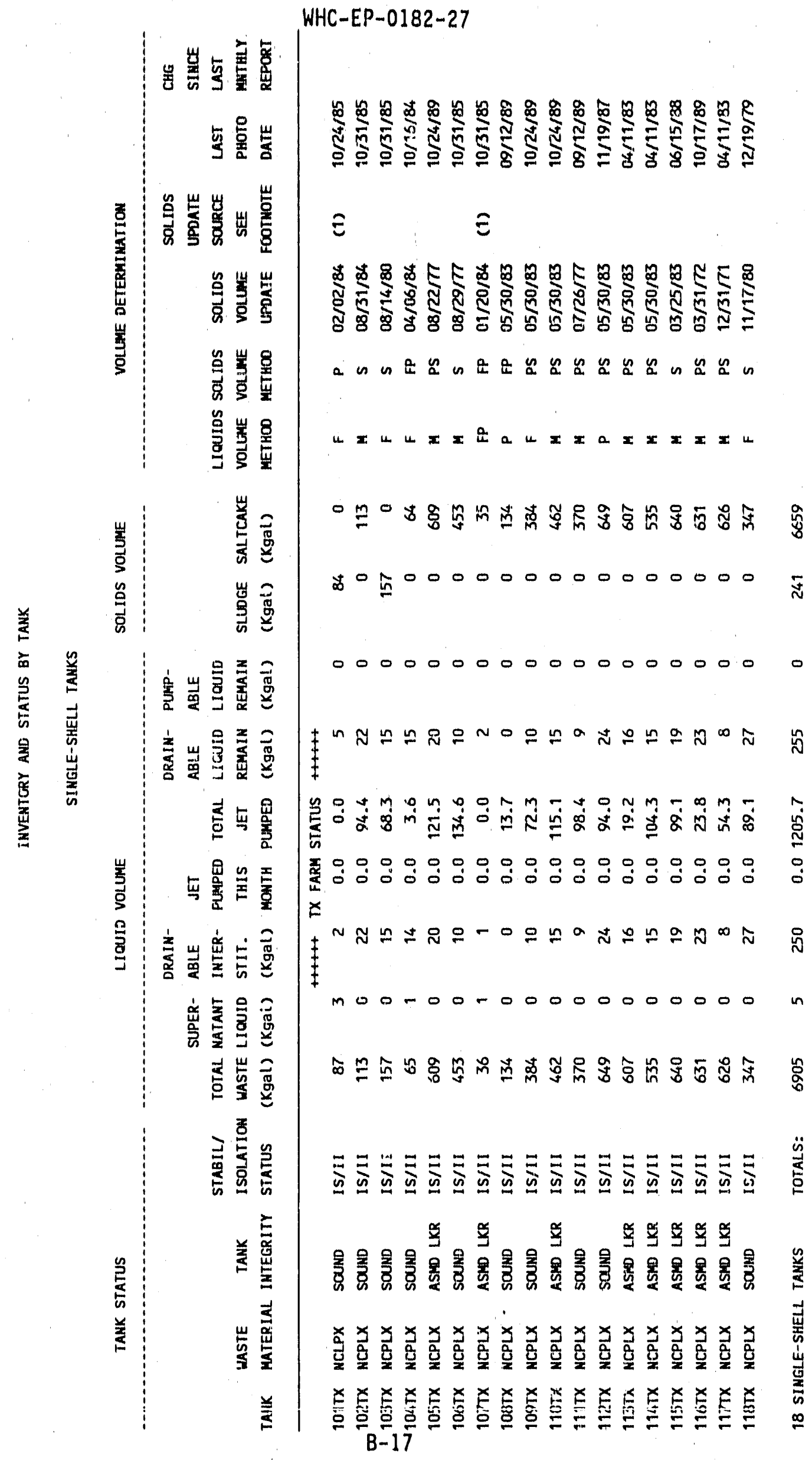




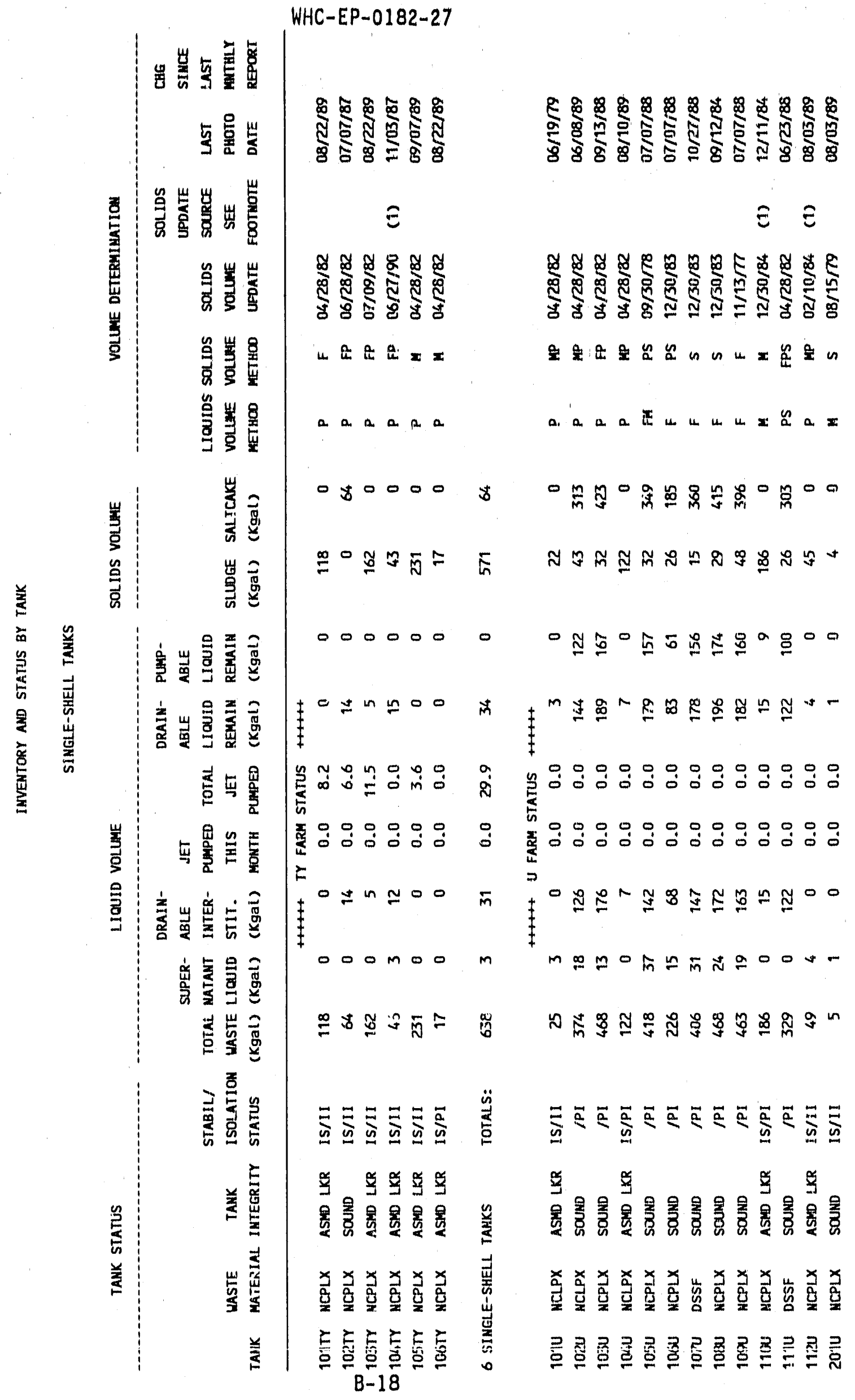




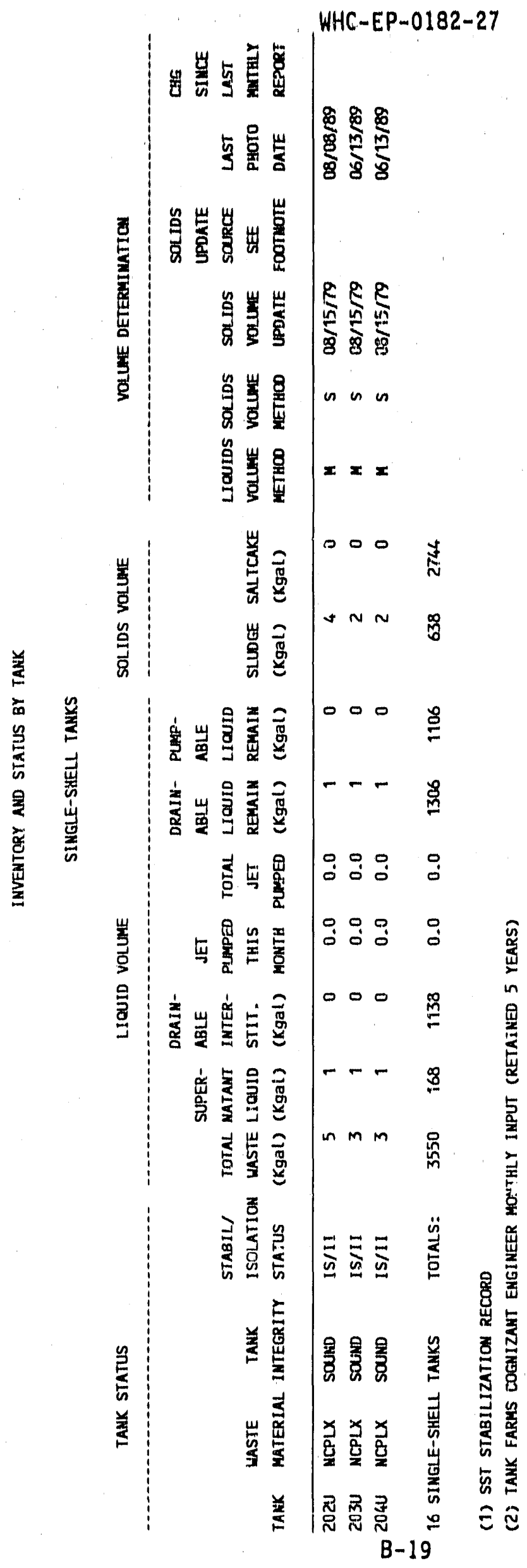


WHC-EP-0172-27

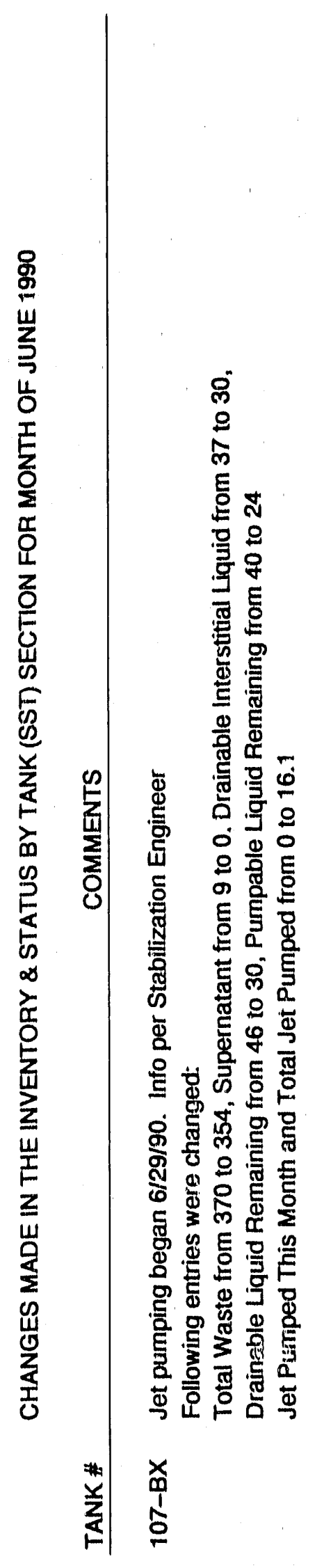


WHC-EP-0182-27

\section{APPENDIX C}

PERFORMANCE SUMMARY

c- $-1 / 2$ 
WHC-EP-0182-27
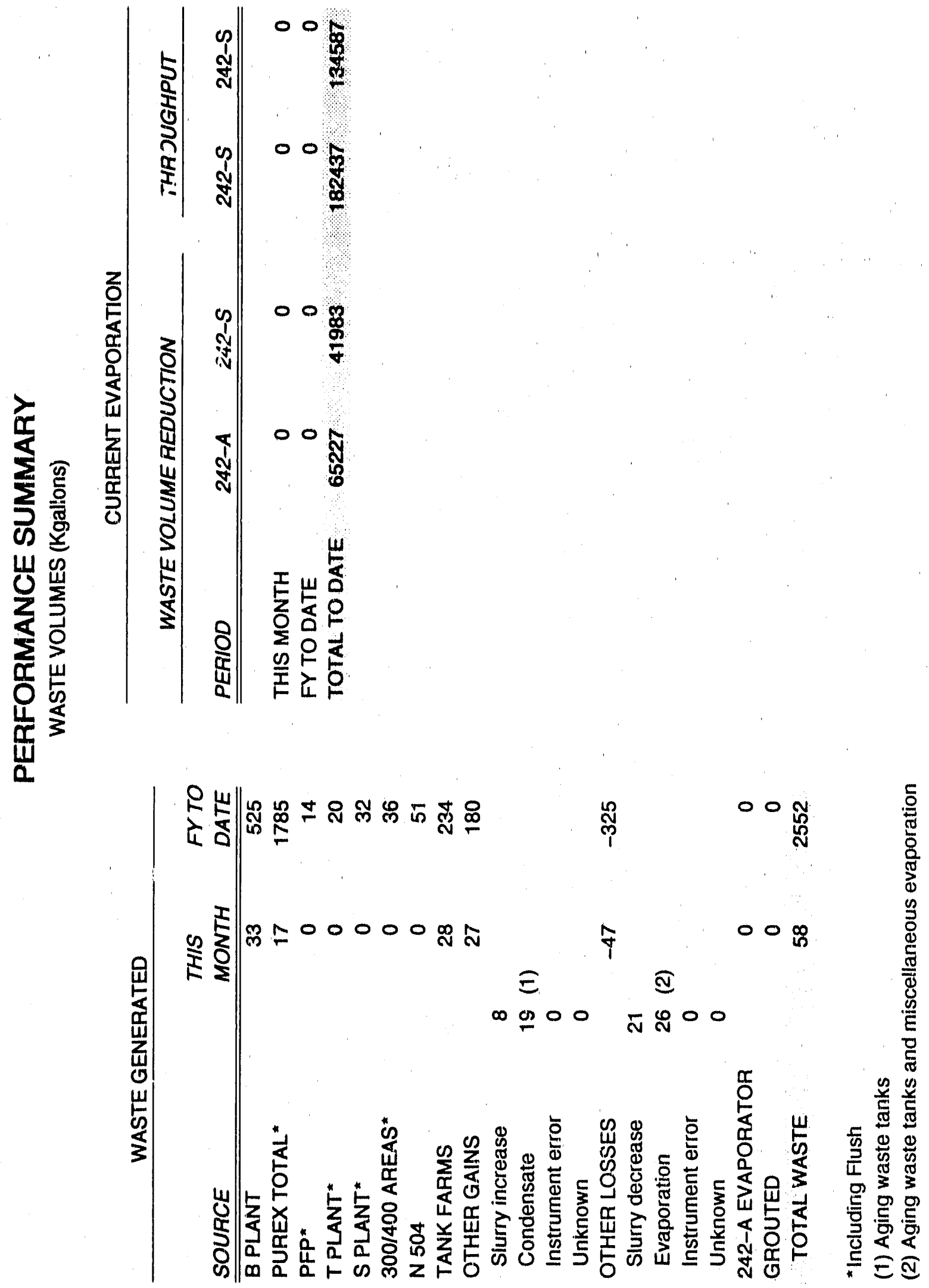

$$
c-3 / 4
$$


WHC-EP-0182-27

APPENDIX D

LIQUID STATUS AND PUMPABLE LIQUID

REMAINING IN TANKS

$0-1 / 2$ 
WHC-EP-0182-27

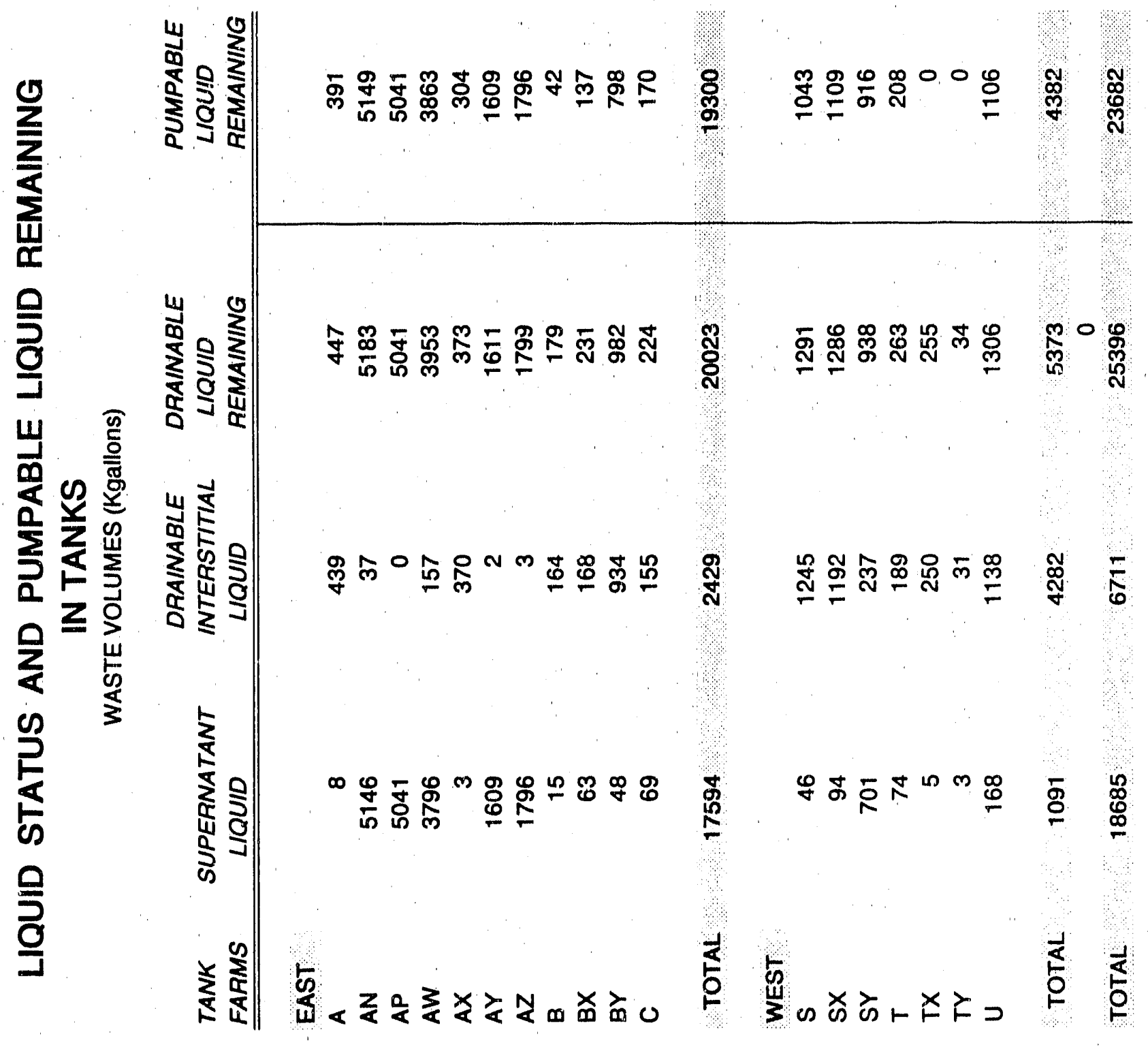


WHC-EP-0182-27

APPENDIX E

SALTWELL PUMPING RECORD.

E-1/2 


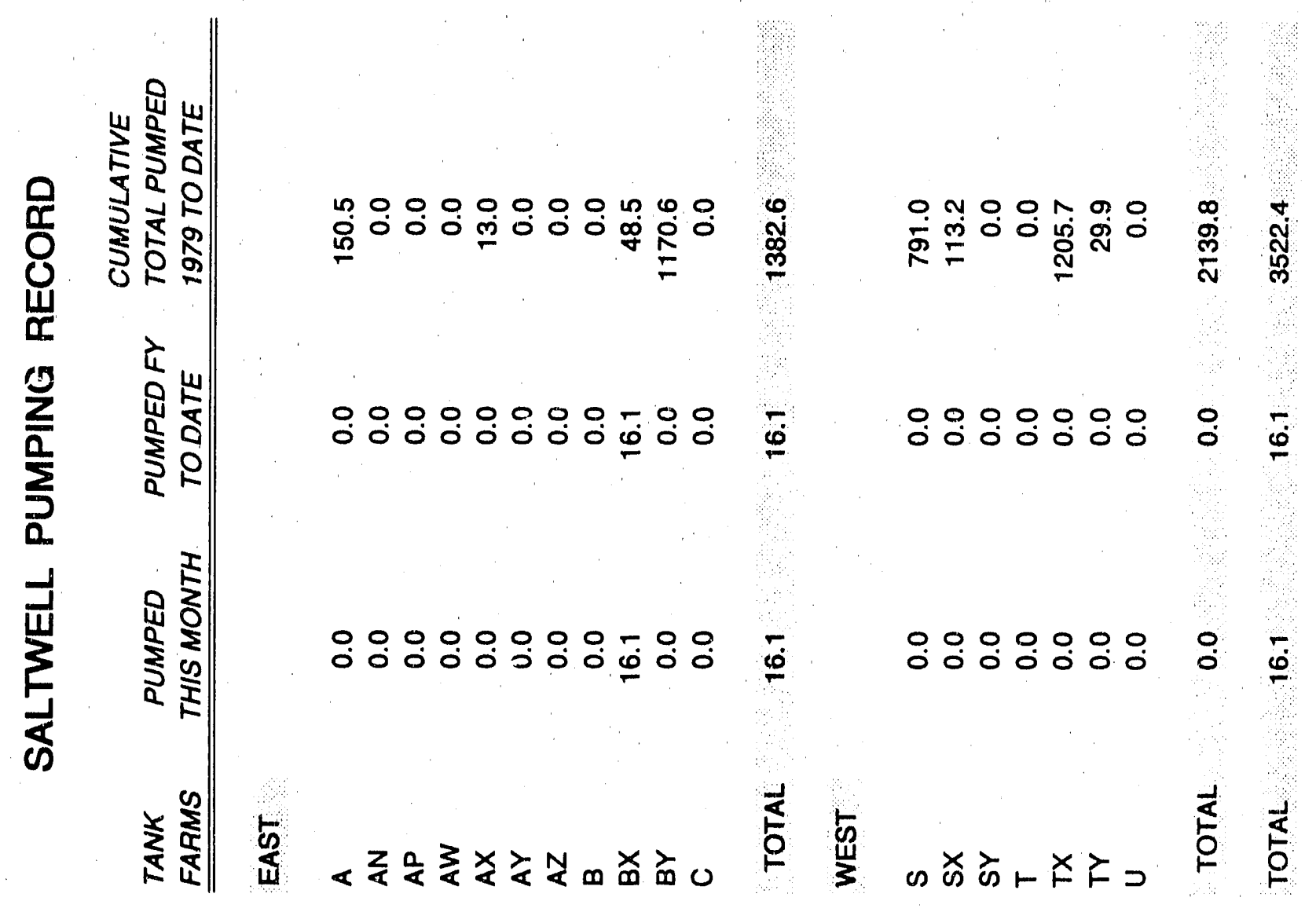


WHC-EP-0182-27

APPENDIX F

CATCH TANKS

$F-1 / 2$ 


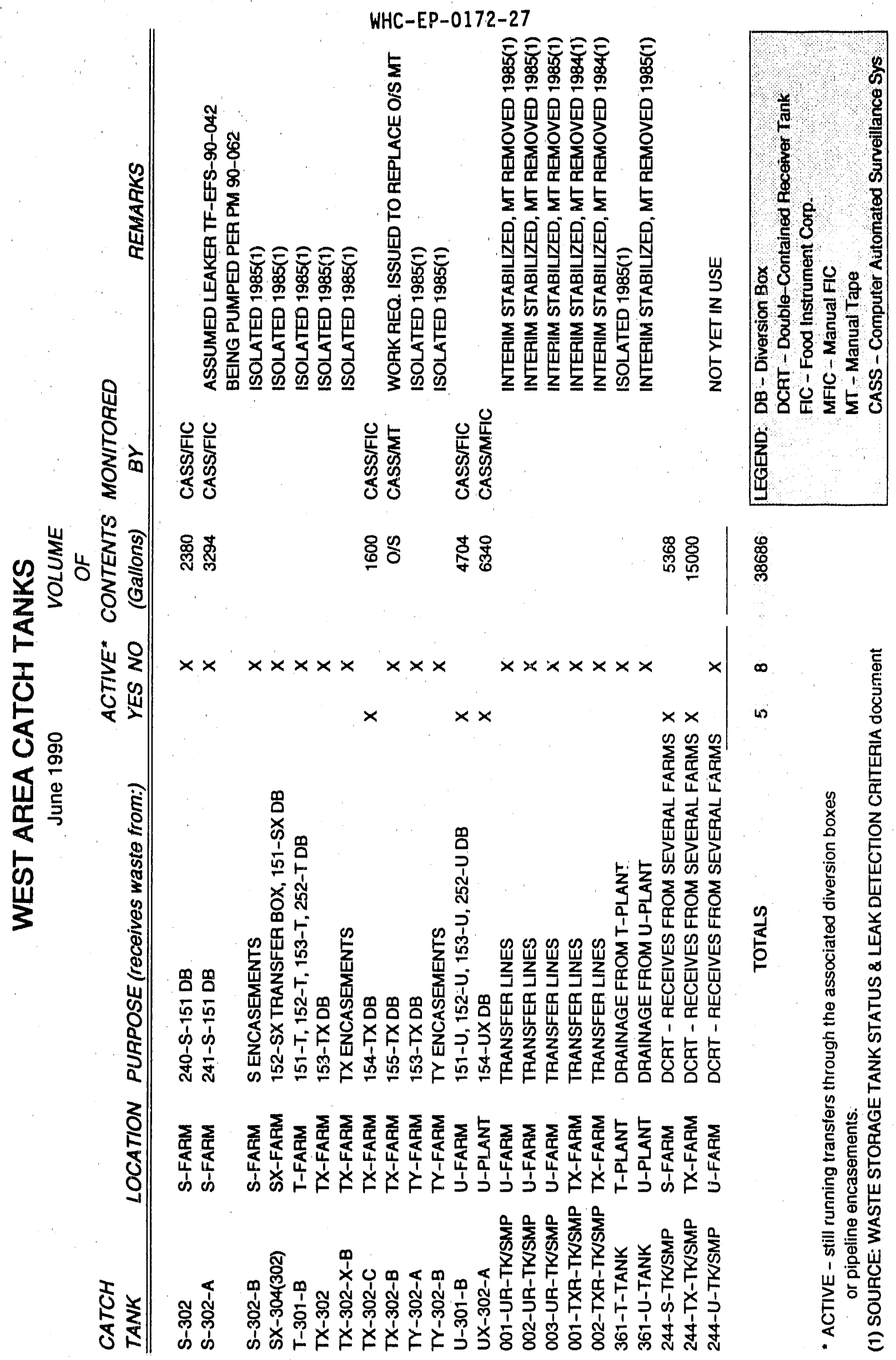




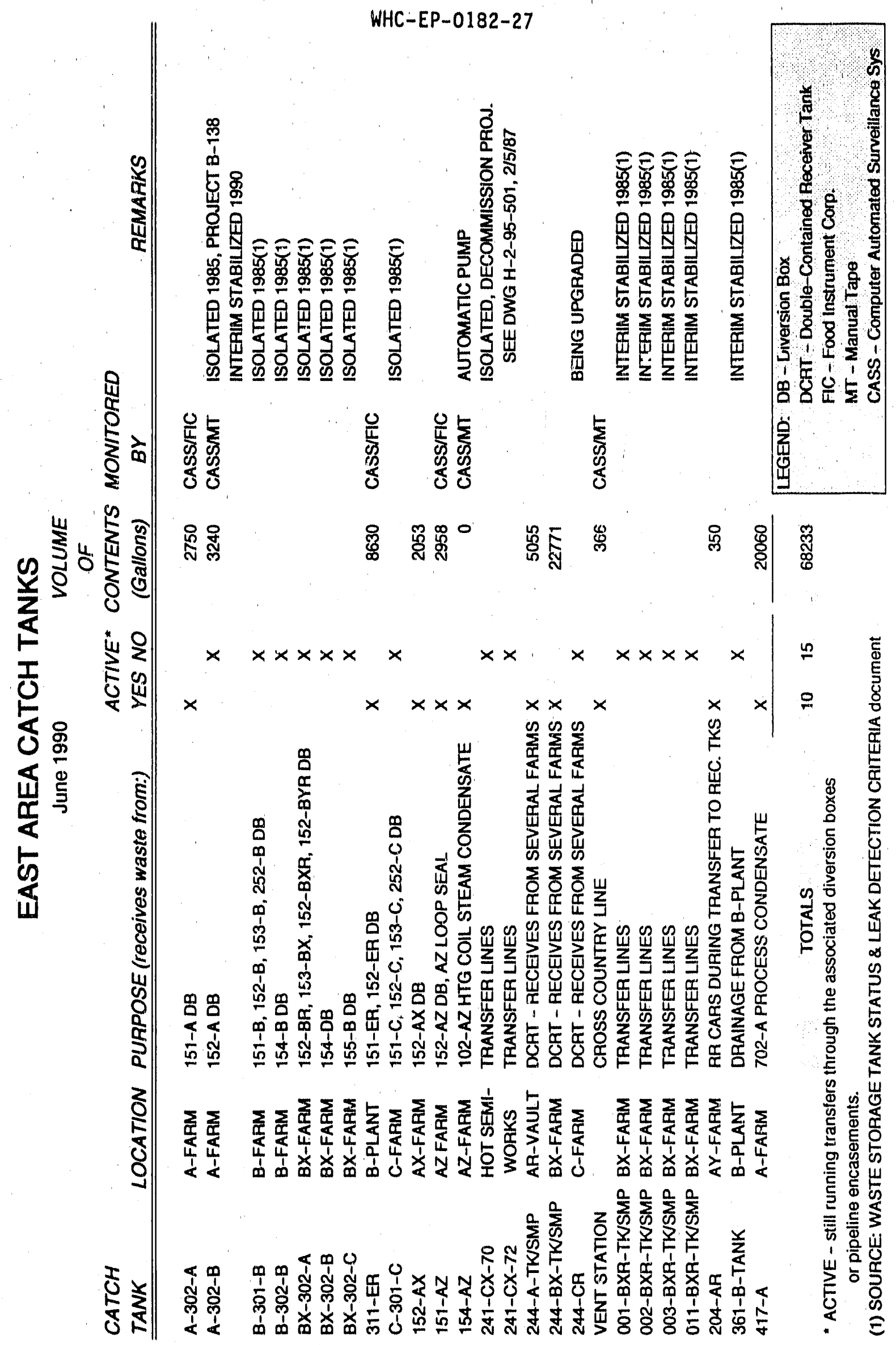


WHC-EP-0182-27

APPENDIX G

TANK LEAK DATA

$G-1 / 2$ 


\section{Table G-1. Leak Volumes Estimated and Reported} Before CY 1989 (39 Tanks)

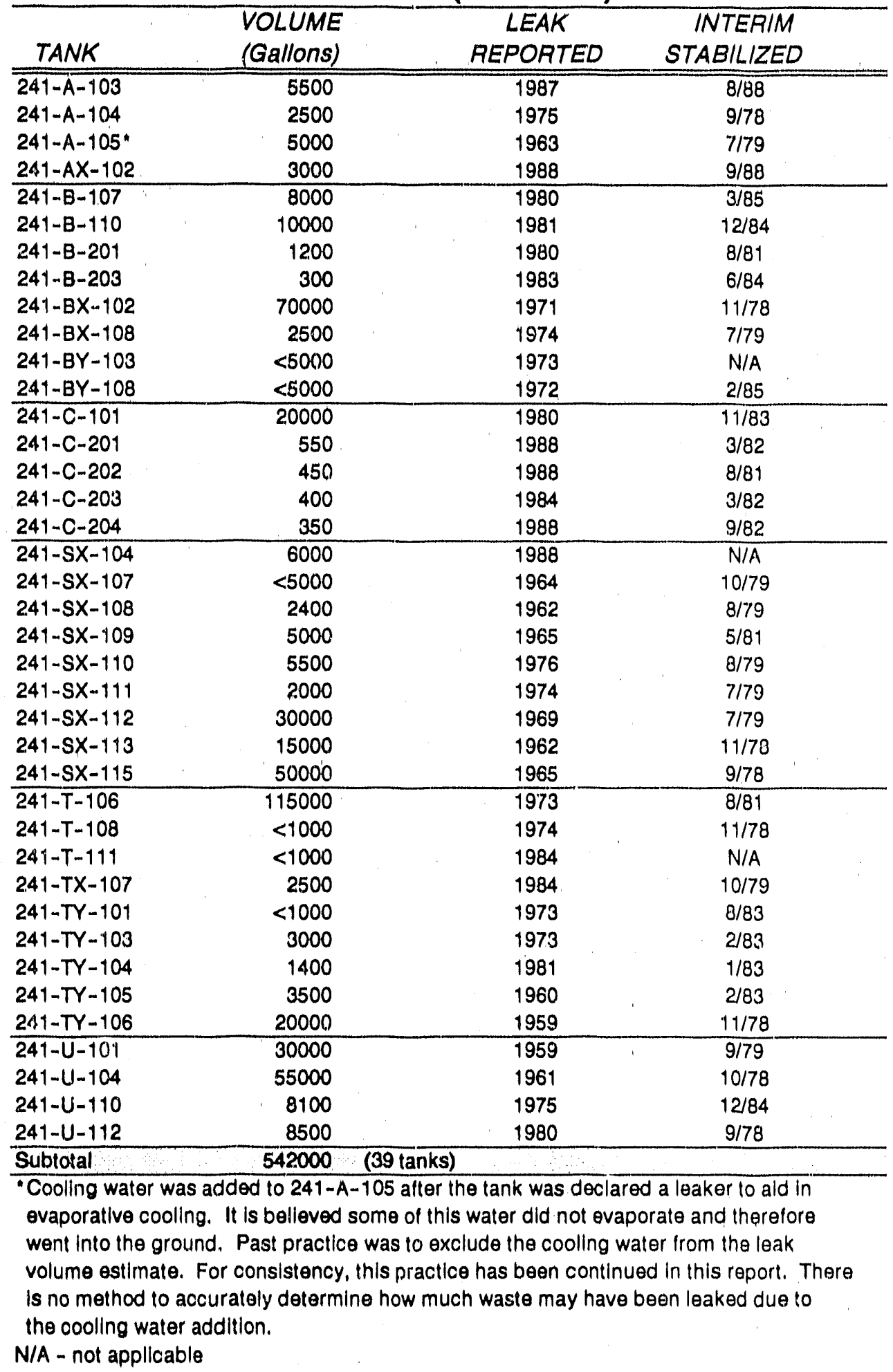


Table G-2. Leak Volumes Estimated in CY 1989 From Previous Assurned Leaking Tanks (27 Tanks)

\begin{tabular}{|c|c|c|c|}
\hline TANK & $\begin{array}{l}\text { VOLUME } \\
\text { (Gallons) }\end{array}$ & $\begin{array}{c}\text { LEAK } \\
\text { REPOATED }\end{array}$ & $\begin{array}{r}\text { INTERIM } \\
\text { STABILIZED }\end{array}$ \\
\hline $241-8-204$ & 400 & 1984 & $6 / 84$ \\
\hline $241-B Y-107$ & 15100 & 1984 & $7 / 79$ \\
\hline $241-C-111$ & 5500 & 1968 & $3 / 84$ \\
\hline $241-5-104$ & 24000 & 1968 & $12 / 84$ \\
\hline $241-T-103$ & $<1000$ & 1974 & $11 / 83$ \\
\hline $241-T-109$ & $<1000$ & 1974 & $12 / 84$ \\
\hline Subtotal & 47000 & (6.Tanks) & \\
\hline $241-B-112$ & 2.000 & 1978 & $5 / 85$ \\
\hline $241-C-110$ & 2000 & 1984 & $N / A$ \\
\hline Sublotal & 4000 & (2 Tanks) & \\
\hline $241-A X-104$ & $-m$ & 1977 & $8 / 81$ \\
\hline $241-8-101$ & $-\cdots$ & 1974 & $3 / 81$ \\
\hline $241-B-103$ & -- & 1978 & $2 / 85$ \\
\hline $241-B-105$ & - & 1978 & $12 / 84$ \\
\hline $241-B-111$ & -- & 1978 & $6 / 85$ \\
\hline $241-B \times-101$ & $-\infty$ & 1972 & $9 / 78$ \\
\hline $241-8 X-110$ & 4 & 1976 & $8 / 85$ \\
\hline $241 \cdots \mathrm{BX}-111$ & -- & 1984 & $N / A$ \\
\hline $241 \ldots B Y-105$ & -- & 1984 & $N / A$ \\
\hline $241-B Y-106$ & - & 1984 & $N / A$ \\
\hline $241-5 x-114$ & -- & 1972 & $7 / 79$ \\
\hline $241-T-10^{7}$ & -- & 1084 & $N / A$ \\
\hline $241-T X-105$ & - & 1977 & $9 / 83$ \\
\hline $241-T X-110$ & -- & 1977 & $4 / 83$ \\
\hline $241-T X-113$ & -- & 1974 & $4 / 83$ \\
\hline $241-T X-114$ & -- & 1974 & $4 / 83$ \\
\hline $241-T X-115$ & $m$ & 1977 & $9 / 83$ \\
\hline $241-T X-116$ & $=-$ & 1977 & $4 / 83$ \\
\hline $241-T X-117$ & - & 1977 & $3 / 83$ \\
\hline Subtatal & 150000 & (a) (19 Tanks) & \\
\hline Subtotal & 201000 & Table G-2 & \\
\hline Subtotal & 542000 & Table G-1 & \\
\hline TOTAL & 750000 & (b) & \\
\hline
\end{tabular}
(a) Estimate rounded to nearest 10000 gallons.
(b) Rounded to nearost 50000 gallons.
N/A - not applicable 


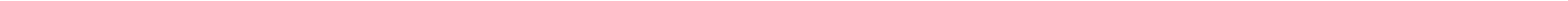


